
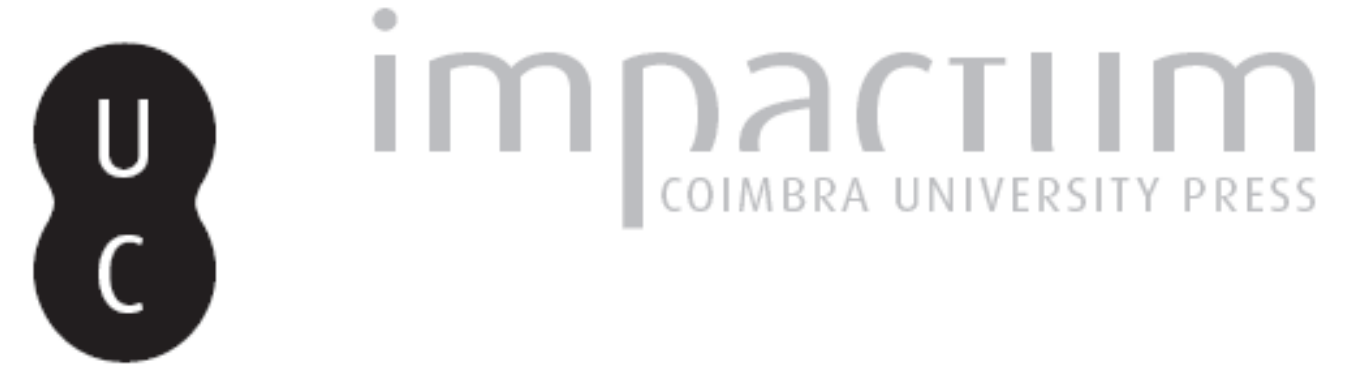

\title{
Vulnerabilidade e risco resultante da ocupação de uma planície aluvial: o exemplo das cheias do rio Mondego (Portugal central), no Inverno de 2000/2001
}

Autor(es): $\quad$ Cunha, P. Proença

Publicado por: Associação Portuguesa de Riscos, Prevenção e Segurança

URL persistente:

URI:http://hdl.handle.net/10316.2/40084

DOI:

DOI:https://doi.org/10.14195/1647-7723_9_2

Accessed : $\quad$ 26-Apr-2023 12:08:14

A navegação consulta e descarregamento dos títulos inseridos nas Bibliotecas Digitais UC Digitalis, UC Pombalina e UC Impactum, pressupõem a aceitação plena e sem reservas dos Termos e Condições de Uso destas Bibliotecas Digitais, disponíveis em https://digitalis.uc.pt/pt-pt/termos.

Conforme exposto nos referidos Termos e Condições de Uso, o descarregamento de títulos de acesso restrito requer uma licença válida de autorização devendo o utilizador aceder ao(s) documento(s) a partir de um endereço de IP da instituição detentora da supramencionada licença.

Ao utilizador é apenas permitido o descarregamento para uso pessoal, pelo que o emprego do(s) título(s) descarregado(s) para outro fim, designadamente comercial, carece de autorização do respetivo autor ou editor da obra.

Na medida em que todas as obras da UC Digitalis se encontram protegidas pelo Código do Direito de Autor e Direitos Conexos e demais legislação aplicável, toda a cópia, parcial ou total, deste documento, nos casos em que é legalmente admitida, deverá conter ou fazer-se acompanhar por este aviso.

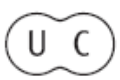




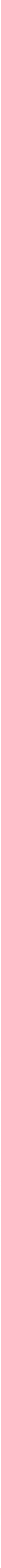




\title{
Vulnerabilidade e risco resultante da ocupação de uma planície aluvial - o exemplo das cheias do rio Mondego (Portugal central), no Inverno de $2000 / 2001^{*}$
}

\author{
P. Proença Cunha**
}

\begin{abstract}
Resumo:
Durante os anos setenta, desenvolveu-se um projecto de protecção maciça de cheias e de modificação dos canais; apesar desses esforços, o rio Mondego reciamou-se numa grande escala no Inverno de 2000/2001. No auge da inundação quase toda a planície aluvial ficou submersa. Apresentam-se estas importantes cheias do rio, constituindo um born exemplo de risco associado a inundaçōes em ambiente terrestre. Descrevem-se os controlos físicos das cheias, os processos e os efeitos das inundações na planície aluvial, a resposta humana, bem como se referem implicações no ordenamento do território e na vulnerabilidade/risco. Palavras chave:

Rio Mondego, Portugal, cheias, riscos de inundações, gestão hídrica, ordenamento do território.
\end{abstract}

Résumé:

Lors des années 70 , un projet de protection des crues et de modification des canaux a été développé; malgré tout ces efforts, durant l'hiver 2000/2001, le fleuve Mondego (centre du Portugal) s'est manifesté en provocant remarquables inondations. À partir de cet exemple, on présente les risques encourus par les inondations terrestres d'un fleuve régularisé. Les contrôles physiques des crues, les processus et les résultats des inondations sur la plaine alluviale en aval de Coimbra et l'intervention humaine ont été analysés dans cet article.

Mots clés:

Fleuve Mondego, Portugal, crues, risques d'inondations, gestion hydrique, aménagement.

Abstract:

During the 1970s, a massive flood protection and channel modification program was developed; in spite of those efforts, the Mondego River asserted itself on a grand scale in the winter of 2000/2001. At the height of the flooding, almost all the alluvial plain was under water. This paper presents these important floods, which constitute a good case study of an inland flood hazard. It addresses physical controls on flooding, flood processes and effects on the alluvial plain, and the human response to flooding. Key words:

Mondego River, Portugal, floods, flood hazards, water management, land planning.

\section{Introdução}

\section{Objectivos}

São objectivos deste trabalho descrever os principais efeitos das cheias do rio Mondego no sector compreendido entre Coimbra e a foz que ocorreram no inverno 2000/2001, dar a conhecer uma síntese dos resultados da monitorização da hidrodinâmica sedimentar em condições de elevada descarga fluvial, entender as principais causas de se ter atingido um tão elevado caudal, bem como referir as inerentes implicações no ordenamento do território e na vulnerabilidade/risco.

\footnotetext{
Investigação no âmbito do Centro de Geociências da Univ. Coimbra Grupode Análise de Bacias, Sistemas e Recursos Sedimentares, financiado pela Fundação para a Ciência e a Tecnologia.

** Departamento de Ciências da Terra da Univ. Coimbra; Largo Marquês de
} Pombal, 3000-272 Coimbra; pcunha@ci.uc.pt.
O estudo destas cheias reveste-se de espectacularidade dado que a 26-27 de Janeiro de 2001 se atingiu em Coimbra um caudal no limiar de colapso das obras hidráulicas do Baixo Mondego que, em regime de caudais regularizados, só deveria ocorrer uma vez em mil anos.

O rio Mondego é o maior rio exclusivamente português e a sua bacia hidrográfica, com $6645 \mathrm{~km}^{2}$, tem uma afluência média anual de cerca de $1213 \mathrm{hm}^{3}$ em ano secoe de $4032 \mathrm{hm}^{3}$ em ano húmido(MARTINS, 1949; PBHM, 1999). Foi há cerca de trinta anos que se iniciaram as obras do projecto de Regularização e AproveitamentoHidroagrícola da Bacia do rio Mondego (RAHBM) (SANCHES, 1996) que, essencialmente, compreende diversas barragens a montante de Coimbra e a canalização a jusante desta cidade (fig. 1 e 2) concluída em 1984. 


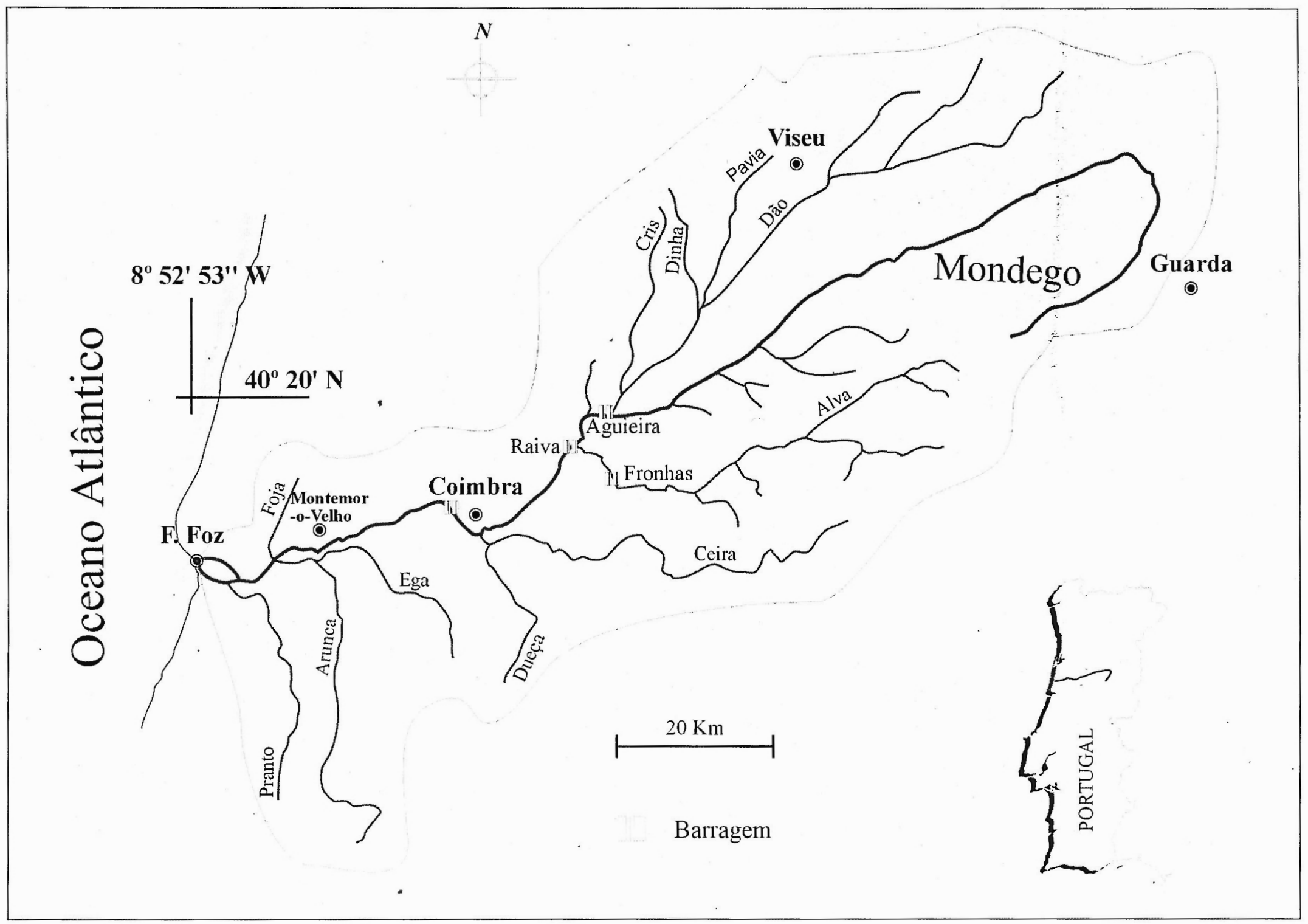

Fig. 1 - Rio Mondego e principais afluentes, bem como as diversas barragens (modif. de MARQUES et al., 2002). A área estuarina situa-se para jusante de Montemor-o-Veiho. 


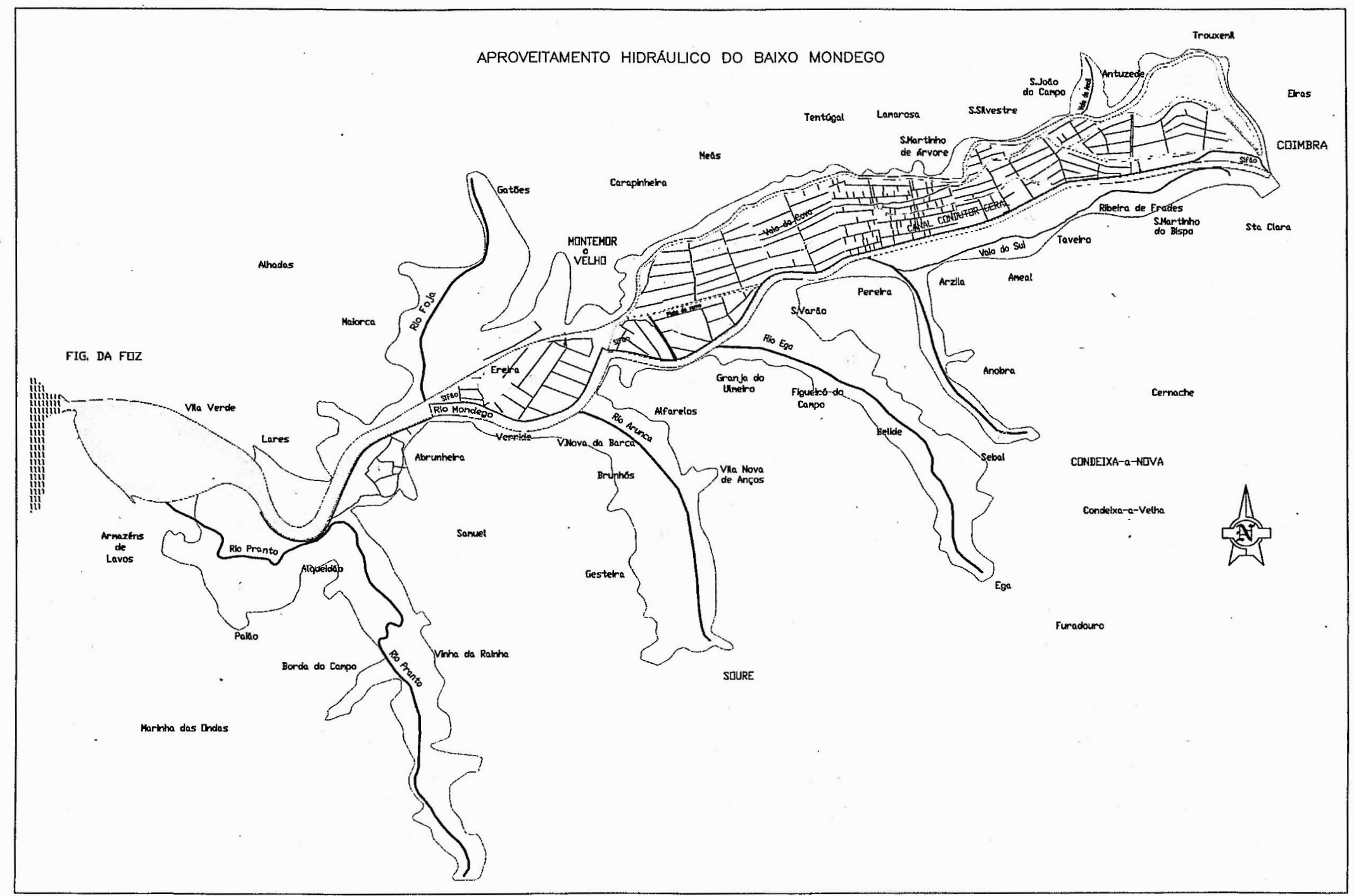

Fig. 2 - Esquema das principais estruturas do aproveitamento hidráulico do Baixo Mondego (adap. a partir de desenho disponibilizado pelo IHERA). O Canal Condutor Geral (C.C.G.) está figurado a negro ao longo da margem direita do Canal Principal do Mondego. Junto ao Iimite norte da planície aluvial situa-se o Leito Periférico Direito (LPD). Junto ao limite sul, entre Coimbra e Pereira, localiza-se o Leito Periférico Esquerdo (LPE). Com as cheias do Inverno de 2000/2001 ficou quase completamente inundada a planície aluvial do Baixo Mondego, compreendendo: os blocos emparcelados (numerados de 1 a 18 e totalizando cerca de 12370 ha; cerca de 400 ha do bloco 17 -S.Martinho não foram inundados), mais os campos da margem esquerda do LPE e os da margem direita do LPD. 
A monitorização das cheias do Mondego tem especial interesse para o conhecimento da hidrodinâmica, em especial do estuário que atinge cerca de $16 \mathrm{~km}$ de comprimento desde Montemor-o-Velho até à Figueira da Foz, dado que são muito escassos os dados publicados sobre as cheias deste rio, quer em regime natural quer em regime regularizado. Embora de rara ocorrência e de curta duração, as situações de cheia revestem-se de grande interesse para o conhecimento da hidrodinâmica sedimentar e muito frequentemente são responsáveis por significativas alterações nas características geomorfológicas do sistema fluvial e estuarino.

\section{Metodologias}

Noperíodo que antecedeu as cheias, o rio Mondego ficou praticamente a seco durante cerca de um mês e meio, desde 14 de Outubro a 30 de Novembro de 2000 , situação excepcional pois esteve aberto o Açude de Coimbra para facilitar a reparação de um muro na margem direita do rio, em Coimbra. Aproveitámos esta muito rara situação para fazer o reconhecimento do leito desde Coimbra até à foz, compreendendo recolha de imagens, descrição e desenho das principais morfologias sedimentares, observação das variações granulométricas laterais e longitudinais, bem como recolha de amostras dos sedimentos para ulterior caracterização laboratorial.

Durante os cerca de dois meses que duraram as cheias, efectuámos: 1) vários reconhecimentos de campo desde a Aguieira até à foz, com registo fotográfico e vídeo; 2) no dia 31 de Janeiro de 2001, foi feita uma campanha de registo das características das águas (velocidade, condutividade, salinidade, temperatura) nos dois braços estuarinos que envolvem a Ilha da Morraceira, através de três estações fixas (nos Cinco Irmãos, foz do Pranto e na Ponte dos Arcos) e de uma móvel ao longo do Braço Norte (através de embarcação deslocando-se desde a foz até à ponte ferroviária de Lares).

Após as cheias, observámos os vários locais onde se verificaram danos, os respectivos trabalhos de reparação, bem como as acumulações de sedimentos fora do leito. Infelizmente, dos leitos no Baixo Mondego não existem dados batimétricos posteriores ao do projecto de regularização (30 anos) e a execução pelo INAG (do perfil topográfico longitudinal e perfis transversais das principais secções) planeada para depois das cheias ainda não se concretizou, por falta de financiamento.

O trabalho de laboratório incidiu na determinação do material em suspensão de amostras recolhidas nas campanhas de final de Janeiro de 2001 e em granulometrias de sedimentos amostrados imediatamente antes e depois destas cheias.
O trabalho de gabinete envolveu a análise de diversos registos de imagem, de dados de caudais do Mondego, de cartas batimétricas do estuário, etc. Note-se que, desde 1995, fizemos vários voos com o objectivo de fotografar o leito do Mondego, a fim de caracterizar qualitativamente as morfologias e os assoreamentos sedimentares de Coimbra até à foz.

Através das várias metodologias acima referidas obtivemos dados que, neste artigo, por limitações de espaço, apenas se apresentam de forma sintética de modo a explicar o fundamental das características das cheias do rio Mondego no Inverno de 2000/2001 e que se pretende pormenorizar em futuras publicações. Previamente foram apresentadas duas comunicações sobre este tema (CUNHA, 2001a, 2001b).

\section{Caracterização das cheias do rio Mondego no Inverno de 2000/2001}

\section{Análise da precipitação atmosférica}

$\mathrm{Na}$ bacia hidrográfica do Mondego a maior precipitação mensal verificou-se junto a Coimbra; assim, a totalização do mês de Janeiro de 2001 apresentou o máximo no concelho de Coimbra, a que corresponde um período de retorno de 90-100 anos que aumenta para cerca de 140 anos se o período de totalização também incluir Dezembro de 2000 (RODRIGUES et al., 2001; fig. 3A). Contudo, tendo em conta o valor médio na totalidade da bacia hidrográfica, para a totalização destes dois meses o correspondente período de retorno perde excepcionalidade e aproxima-se de uma frequência centenária.

Note-se que a pluviosidade contínua ocorreu desde inícios de Novembro de 2000, o que contribuiu para a saturação dos solos e subida dos níveis freáticos da bacia hidrográfica e consequente reforço da relação entre os momentos de precipitação mais intensa e a geração de pontas de cheia a jusante.

Relativamente à precipitação atmosférica durante períodos curtos, determinante nas pontas de cheia, o valor máximo em $24 \mathrm{~h}$ foi atingido a 26-27 de Janeiro de 2001, com um período de retorno que atingiu 70-150 anos numa área centrada em Santa Comba Dão(RODRIGUES et al., 2001; fig. 3B). Mas também relativamente a este parâmetro, se considerarmos a precipitação na totalidade da bacia hidrográfica, a respectiva excepcionalidade decresce significativamente.

Segundo a análise de N. Ganho (comunicação oral, 2001), os valores dos registos do Instituto Geofísico da Universidade de Coimbra no período 1891-1990 não foram, de Outubro de 2000 a Março de 2001, ultrapassados no que respeita à precipitação máxima em 1 h, em $24 h$, ena totalização para Novembro- 
Dezembro (em que choveu durante 49 dias), nem para o conjunto destes seis meses. Também não se excedeu o valor máximo mensal ( $467 \mathrm{~mm}$-Novembro de 1963; período 1941-94) (LIMA \& LIMA, 2002).

\section{Análise dos caudais e da gestão hídrica}

As barragens da Aguieira e de Fronhas foram construídas para assegurar a regularização de cerca de $80 \%$ da bacia hidrográfica a montante de Coimbra. A albufeira da Aguieira temcota máxima de enchimento de $125 \mathrm{~m}$, a que corresponde uma capacidade de armazenamento de 423 milhões de metros cúbicos $\left(\mathrm{hm}^{3}\right)$. Por ter a principal função de amortecimento das pontas de cheia nos períodos de forte precipitação, o projecto inicial (que data da década de 60) considerava desejável que durante o Inverno a albufeira fosse explorada apenas à cota $112,5 \mathrm{~m}$, a que correspondem $277 \mathrm{hm}^{3}$ e $66 \%$ da capacidade. Note-se que esta albufeira precisa de $265 \mathrm{hm}^{3}$ para encaixar a afluência de uma cheia centenária (Tab. 1) e nesta situação ainda chegariam a Coimbra $1200 \mathrm{~m}^{3} / \mathrm{s}$ provenientes do rio Ceira e da restante parte da bacia não regularizada (SANCHES, 1996).

No entanto, após a conclusão da barragem, em 1979 , a cota de exploração subiu dos $112,5 \mathrm{~m}$ para $116 \mathrm{~m}$ (a que correspondem $327 \mathrm{hm}^{3}$ ) por razões de produção de energia hidroeléctrica e para captação de água para abastecimento público; ou seja, retirou-se cerca de $50 \mathrm{hm}^{3}$ na folga de segurança contra cheias (P. VIEIRA in Expresso de Fevereiro de 2001).

A. Santos Veloso (comunicação oral, 2001), considerou muito anormal que nos últimos doze anos se tenha registado em Coimbra, por cinco vezes, um caudal $\left(1200 \mathrm{~m}^{3} / \mathrm{s}\right)$ que o projecto RAHBM especificava só dever ocorrer apenas uma vez por século, o que significa que a Aguieira não estaria a fazer uma boa gestão dos caudais de cheia. Assim, aquele valor foi ultrapassado em 21 de Dezembro $1989\left(1599 \mathrm{~m}^{3} / \mathrm{s}\right), 9$ de Janeiro $1996\left(1229 \mathrm{~m}^{3} / \mathrm{s}\right)$, 7-8 Dezembro $2000\left(1613 \mathrm{~m}^{3} / \mathrm{s}\right)$, 5-6 Janeiro 2001 $\left(1625 \mathrm{~m}^{3} / \mathrm{s}\right)$ e $26-29$ Janeiro $2001\left(1942 \mathrm{~m}^{3} / \mathrm{s}\right)$. Estava também previsto no projecto que a gestão integrada dos aproveitamentos hidráulicos na bacia do Mondego deveria assegurar que caudais da ordem dos 2000 $\mathrm{m}^{3} / \mathrm{s}$ em Coimbra tivessem uma frequência de ocorrência muito baixa, da ordem de uma vez em 1000 anos, para evitar a inundação da baixa da cidade e o colapso da obra hidráulica a jusante (LENCASTRE \& FRANCO, 1984, p. 391-395).

No Inverno de 2000/2001, o Instituto da Água (INAG) - entidade do Ministério do Ambiente responsável pela gestão das obras hidráulicas - teve dificuldade em «amortecer» os picos de cheia.
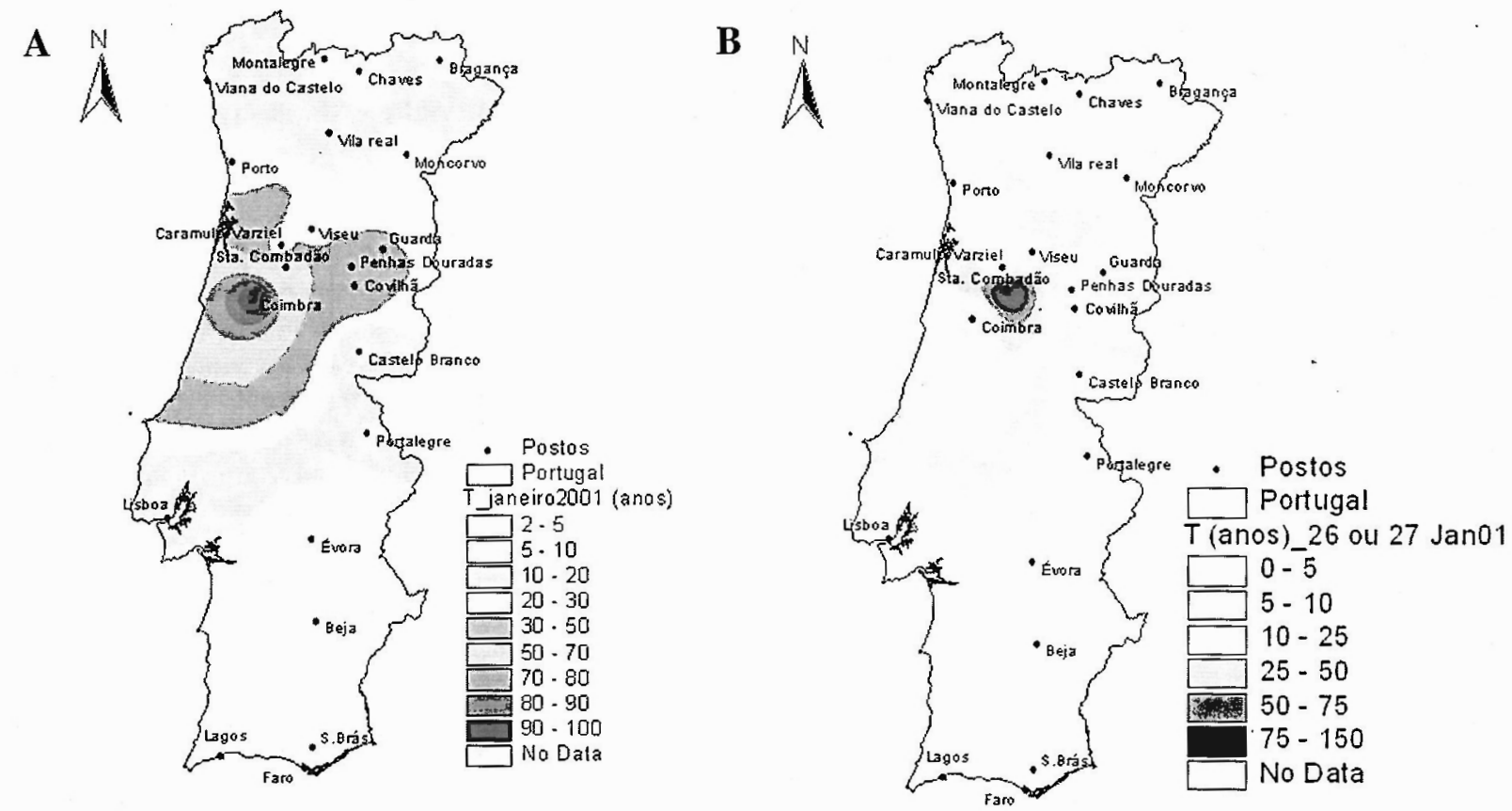

Fig. 3 - Excepcionalidade da precipitação atmosférica, expressa através do respectivo período de retorno (adaptado de RODRIGUES et al., 2001): A) Valor máximo da precipitação mensal, expresso pela totalização da precipitação de Janeiro de 2001;

B) Valor máximo da precipitação em 24h, ocorrida a 26-27 de Janeiro de 2001. 
A primeira situação crítica do Inverno surgiu com o temporal de 7 de Dezembro de 2000, tendo a albufeira da Aguieira ficado muito cheia (fig. 4). O caudal afluente a Coimbra atingiu os $1613 \mathrm{~m}^{3} / \mathrm{s}$ no dia $8 \mathrm{de}$ Dezembro, transbordando para as margens. O Ceira transbordou e apresentava descarga intensa e rica de sedimentos em suspensão; note-se que recentemente tinham ocorrido incêndios nas zonas montanhosas a montante, o que favoreceu a erosão dos solos a quando das primeiras chuvas. Imediatamente a jusante de Coimbra, no troço de Casais, a água chegou a galgar com $20 \mathrm{~cm}$ o dique esquerdo

\begin{tabular}{|c|c|c|}
\hline & Açude de Coimbra & Figucira da Foz \\
\hline $\begin{array}{c}\text { Cheia centenária } \\
\text { cm regime natural } \\
\text { (situąão pristina) }\end{array}$ & $3.663 \mathrm{~m}^{3} / \mathrm{s}$ & $?$ \\
\hline $\begin{array}{c}\text { Cheia centenária em regime } \\
\text { amortecido por barragens } \\
\text { (de finido cm projecto) }\end{array}$ & $1.200 \mathrm{~m}^{3} / \mathrm{s}$ & $2.955 \mathrm{~m}^{3} / \mathrm{s}$ \\
\hline $\begin{array}{c}\text { Cheia de 26-29 Janciro 2001, } \\
\text { se não existisse controlo de } \\
\text { caudal por barragens }\end{array}$ & $\begin{array}{c}2.800 \mathrm{~m}^{3} / \mathrm{s} \\
\text { (estimado pclo INAG, por } \\
\text { simulação da chcia natural) }\end{array}$ & $\begin{array}{c}3.400 \mathrm{~m}^{3} / \mathrm{s} \\
\text { (estimado pclo INAG, } \\
\text { por simulação) }\end{array}$ \\
\hline $\begin{array}{c}\text { Cheia de 26-29 Janciro 2001, } \\
\text { caudal ocorrido }\end{array}$ & $1.942 \mathrm{~m}^{3} / \mathrm{s}$ & $\begin{array}{c}\text { scria de } 2.470 \mathrm{~m}^{3} / \mathrm{s} \\
\text { se não tivessem ocorrido } \\
\text { rupturas nos diques a montante }\end{array}$ \\
\hline
\end{tabular}

Tab. I - Caudais afluentes a Coimbra e à Figueira da Foz, em regime natural (situação prístina, regime não modificado por intervenção humana) e em regime regularizado. Valores de caudais segundo SANCHES (1996) ou pelo INAG (os deste Inverno).

do Canal Principal e foi efectuado um reforço de emergência pelo INAG, sob indicação da Assoc. de Benef. da Obra de Fom. Hidroag. do Baixo Mondego (Eng. Ferreira dos Santos, informação oral, 2001).

No mês seguinte a situação repetiu-se (fig. 4). A segunda ponta de cheia ocorreu a 5-6 de Janeiro de 2001 , com o caudal afluente a Coimbra a atingir os $1625 \mathrm{~m}^{3} / \mathrm{s}$. A terceira ponta de cheia, a de maior gravidade, ocorreu a 26-29 de Janeiro de 2001. Nas últimas $12 \mathrm{~h}$ do dia 26 de Janeiro o caudal afluente à albufeira da Aguieira (que estava a $75 \%$ da sua capacidade) passou de 600 para $1860 \mathrm{~m}^{3} / \mathrm{s}$. A barragem, a partir das 9 h do dia 27 , num período de cerca de 24 h subiu a descarga fixa de 513 para $1100 \mathrm{~m}^{3} / \mathrm{s}$, caudal que depois manteve durante cerca de $12 \mathrm{~h}$ (foto $6 \mathrm{e}$ 7). À descarga da Aguieira somava-se ainda o caudal proveniente da barragem de Fronhas (rio Alva) e o caudal do rio Ceira, não regularizado, e que terá atingido cerca de $660 \mathrm{~m}^{3} / \mathrm{s}$. Note-se que a meio da tarde do dia 27 quase se atingiu a cota máxima da barragem (a $70 \mathrm{~cm}$ do galgamento, $96 \%$ da capacidade). Caso um dia ocorresse cedência e ruptura da barragem, isso teria consequências desastrosas para a Baixa de Coimbra e Baixo Mondego.

Segundo simulação pelo INAG em modelo hidrológico HMS (RODRIGUES et al., 2001), na ausência de qualquer controlo a montante o caudal teria atingido $2800 \mathrm{~m}^{3} / \mathrm{s}$ no Açude de Coimbra ao invés dos 1942 $\mathrm{m}^{3} / \mathrm{s}$ registados a 27 de Janeiro de 2001, enquanto que o caudal afluente à Figueira da Foz teria atingido cerca de $3400 \mathrm{~m}^{3} / \mathrm{s}$ em regime natural e cerca de 2470 $\mathrm{m}^{3} / \mathrm{s}$ com o modesto encaixe efectuado pela Aguieira (Tab. 1). Contudo, segundo o relatório elaborado por um grupo de trabalho da Ordem dos Engenheiros (Região Centro) e do Departamento de Eng. Civil da Univ. Coimbra, a barragem da Aguieira podia ter controlado melhor este pico de cheia (SANTOS et $a l ., 2001)$. Note-se que antes da regularização fluvial o caudal de cheia centenária em Coimbra foi calculado em $3663 \mathrm{~m}^{3} / \mathrm{s}$ (D.G.R.A.H., 1987). O impressionante da situação resulta de uma barragem construída com a principal função de evitar os caudais de cheia, ter descarregado cerca de $1000 \mathrm{~m}^{3} / \mathrm{s}$ durante $24 \mathrm{~h}$, em que justamente devia estar a encaixar uma ponta de cheia que em condições naturais nem seria de grandeza centenária. No contexto actual de minimização da capacidade de encaixe de pontas de caudal afluente à barragem da Aguieira, para maximizar outras funções, tais como a produção de electricidade ou o abastecimento de água (agricultura, indústria e consumo doméstico), dificilmente os esforços na previsão hidrológica incorporada no Sistema de Vigilância e Alerta do INAG podem contribuir significativamente para evitar pontas de cheia no Baixo Mondego e a provável inundação das casas construídas na planície aluvial.

\section{Dinâmica fluvial e estuarina}

\section{Transporte sedimentar}

Devido à construção de barragens no sector a montante, o Mondego já não faz o transporte tractivo (areias e sedimentos mais grosseiros) de montante para jusante da Barragem da Aguieira o que, adicionado à contínua extracção de areias nos troços fluviais e estuarinos, contribui para uma progressiva escassez sedimentar, que se evidencia pelo aprofundamento geral dos leitos dos rios e recuo erosivo das praias arenosas (CUNHA \& DINIS, 2000, 2002). Como pudemos constatar através de reconhecimentos que efectuámos periodicamente após 1995, antes das cheias do Inverno de 2000/2001 o Canal Principal do Mondegoencontrava-se significativamente assoreado no troço entre o "açude" de Formoselha-Santo Varão e Ribeira de Frades. Este açude (foto 15) foi construído quando se implantaram as fábricas de papel na Figueira da Foz, para permitir a admissão de água nos curtos períodos em que o Canal Colector Geral (vulgarmente designado por "canal de rega") estivesse inoperacional. Contudo, este açude promoveu grande assoreamento 


\section{Evolução dos caudais}

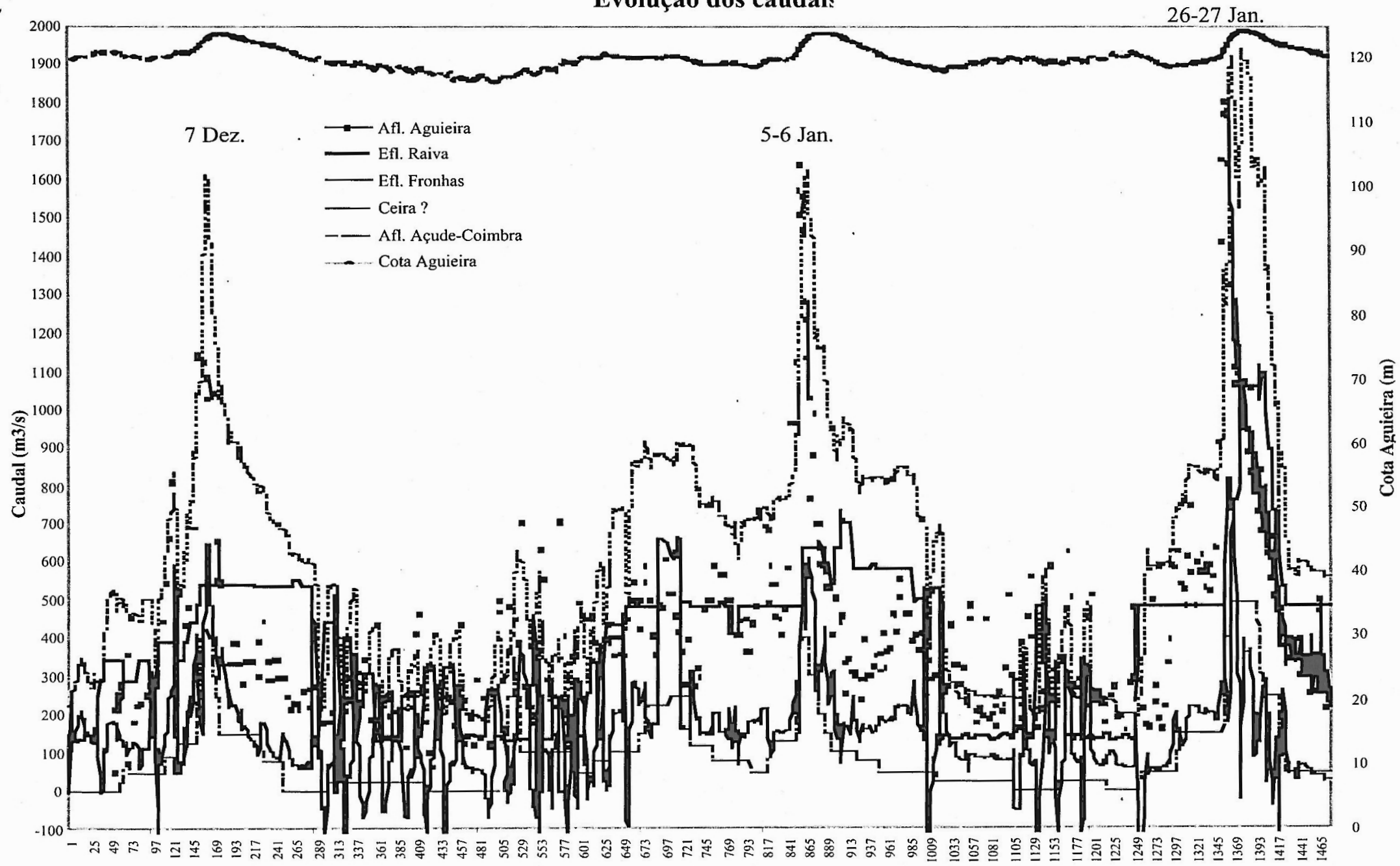

Dezembro de 2000 e Janeiro de 2001

Fig. 4-Caudais afluentes e efluentes às principais barragens da bacia hidrográfica do Mondego, bem como a cota da água na barragem da Aguieira (curva na parte superior do gráfico, rondando os $120 \mathrm{~m}$ de profundidade), durante os meses de Dezembro de 2000 e Janeiro de 2001 (valores do INAG). O caudal estimado para o Ceira resultou da diferença 
a montante; por exemplo, junto a Pereira, no meio do canal existiam ilhas permanentes com árvores (foto 4) e aí se fazia extracção de areia.

A regularização de caudais e a retenção de sedimentos nas albufeiras das barragens contribuiu também para uma diminuição do transporte de sedimentos em suspen são, que só é significativo durante cheias, bem expresso pela cor avermelhada e turva da água naqueles períodos. A progressiva redução dos volumes úteis das albufeiras da Aguieira e de Fronhas, por assoreamento, não se encontram quantificados.

É durante a forte descarga fluvial que se definem as principais morfologias de leito (barras, canais, etc.) que podem ser posteriormente retocadas, sob mais fraca descarga fluvial; no estuário também intervêm as alternantes correntes de enchente e de vazante. Em situação de grande descarga fluvial, o transporte sedimentar para jusante incrementa muito e consegue fornecer sedimentos à deriva litoral. $\mathrm{Na}$ desembocadura, a intensa descarga aprofunda o canal e deposita as areias no mar, formando um delta de vazante.

Com as cheias de 2000/2001, a capacidade de transporte sedimentar atingiu valores muito elevados. Assim, ocorreu transporte das areias e balastros que se encontravam a jusante da barragem da Aguieira; uma parte destes sedimentos ficou retida pelo Açude de Coimbra, que imediatamente a montante se encontrava muito assoreado, e o restante passou durante os períodos em que as comportas estiveram completamente abertas. Da acumulação imediatamente a jusante do Açude de Coimbra (essencialmente areão), $8600 \mathrm{~m}^{3}$ foram removidos (de Dezembro de 2001 a Janeiro de 2002) e vendidos. Mais para jusante, ao longo do Canal Principal do Mondego, a capacidade de transporte permaneceu elevada, como se documentou pelo arrasto, ao longo de centenas de metros, de grandes lajes de betão (Eng. Ferreira dos Santos, informação oral, 2001).

Nestas cheias, para além de um significativo abastecimento de areias ao litoral, acumulou-se também nas praias junto da foz do Mondego uma grande quantidade de materiais arrancados das margens e transportados em flutuação pelo rio (foto 5), alguns de grande dimensão, como troncos de árvores e enormes tubagens destinadas a um adutor hidráulico a construir a norte da Ereira (principalmente arrastados no primeiro pico de cheia, a 7-8 de Dezembro de 2000). De 23 a 28 de Janeiro de 2001 ocorreu forte agitação marítima, com ondulação dominante de $\mathrm{W}$ e que atingiu cerca de 6-7 $\mathrm{m}$ de altura ao largo e 4-5,5 $\mathrm{m}$ junto ao Cabo Mondego, com o consequente rebaixamento erosivo das praias. No Cabedelo (imediatamente a sul da foz do Mondego) o mar galgou em dois sítios, mas não provocou danos.

\section{Descrição das inundações em finais de Janeiro de 2001}

Na manhã do dia 27 de Janeiro de 2001, em Coimbra era grande a inundação do leito de cheia, pois estava submersa uma parte significativa das margens do Mondego (foto 8).

Para jusante, verificou-se pelas $1 \mathrm{~h} 30 \mathrm{~m}$ uma grave situação com a ruptura do dique esquerdo do Canal Principal em Ribeira de Frades-Casais do Campo, junto aos edifícios de uma quinta agrícola, provocando o afogamento dos animais e obrigando ao resgate dos caseiros por helicóptero; também foram descarregadas toneladas de pedras para o talude da auto-estrada A1, que estava a ser erodido lateralmente pelo fluxo torrencial (foto 1 ).

O elevado caudal em trânsito desencadeou vários outros galgamentos do dique esquerdo do Canal Principal (note-se que os diques longitudinais são designados tecnicamente por "diques insubmersíveis") que evoluíram para rupturas. Assim, ocorreu o rápido alagamento do sector oriental da planície aluvial (foto 9) que apanhou desprevenidas as populações da margem esquerda, nomeadamente de Santo Varão, Formoselha e Pereira do Campo; a inundação chegou a atingir $3 \mathrm{~m}$ de altura.

No final da tarde, entre S. Martinho de Árvore e Tentúgal, ficou submersa uma das faixas da estrada EN-111. A situação mais dramática verificou-se em Montemor-o-Velho onde, pelas $21 \mathrm{~h}$, o galgamento e ruptura do dique no Leito Periférico Direito provocou inundações que deixaram mais de uma centena de pessoas desalojadas e a queda da ponte das Lavandeiras (EN-347) (foto 11); o nível da água terá atingido o da grande cheia de 1948, e importantes estruturas, como o Quartel de Bombeiros e o Centro de Saúde, foram inundadas por terem sido construídas na planície aluvial.

Na madrugada do dia 28 de Janeiro de 2001 a inundação das margens do Mondego junto a Coimbra atingiu o valor máximo (foto 10 ), muito próximo da cota da baixa citadina; note-se que a cota máxima de descarga no Açude foi de $18,7 \mathrm{~m}$ que se manteve das $18 \mathrm{~h}$ do dia 27 até às $2 \mathrm{~h}$ do dia 28 , devido a um caudal que quase atingiu $2000 \mathrm{~m}^{3} / \mathrm{s}$. A planície aluvial . estava inundada desde os Campos do Bolão até Montemor-o-Velho, levandoà interrupçãoda circulação ferroviária. No estuário a descarga não era muito elevada, devido às muitas perdas de água para a planície aluvial a montante. Nesse dia efectuámos o registo de características físico-químicas das águas estuarinas, junto ao Cais Comercial (Braço Norte) e na ponte dos Arcos (Braço Sul). Nas praias da embocadura, sujeitas a forte agitação marítima, continuavam a acumular-se materiais transportados 
por flutuação pelo rio Mondego. Durante a tarde a água continuou a subir na planície aluvial, principalmente na margem direita do Mondego; Assim, a Ereira estava convertida em ilha, a estrada IP3 ficou progressivamente submersa e o nível de água era já muito elevado nos campos junto da Estação elevatória de Foja (a $16 \mathrm{~km}$ da foz). No final do dia 28, em Montemor-o-Velho, rompeu-se artificialmente o dique esquerdo do Leito Periférico Direito para que a inundação na povoação diminuísse, conduzindo o escoamento para os campos.

Na madrugada de 29 de Janeiro de 2001 ocorreu junto a Santo Varão uma grande ruptura no dique direito do Canal Principal do Mondego, que introduziu grande caudal nos campos seguindo o antigo leito em direcção a Montemor-o-Velho. Consequentemente, o fluxo vindo de Santo Varão (foto 2) passou a atravessar o Leito Periférico Direito passando pelas duas rupturas (foto 3 ), aumentando a inundação em Montemor e Ereira (foto 12). Devido à tendência de deslocação para jusante dos volumes de inundação nas planícies aluviais, o nível nas zonas alagadas mais distais chegou a estar mais elevado do que a água no Leito Central. Assim, na tarde do dia 29 de Janeiro, a inundação galgou e rompeu o dique direito, junto à Estação elevatória de Foja, começando a escoar-se para o Mondego (foto 13). Nesse dia Lares foi a zona mais atingida pelo aumento do nível de água, com inundação completa dos campos e inundação parcial do armazém da Vidreira do Mondego, bem como isolamento da povoação. A grande inundação impedia o trânsito nas estradas EN111, IP3, EN347 e EN341.

A 30 de Janeiro, para o escoamento da água que ainda se concentrava em Lares, a Protecção Civil decidiu romper o dique ${ }^{1}$ direito do Canal Principal, mais a jusante, junto da ponte ferroviária; deste modo, a inundação diminuiu progressivamente. No concelho da Figueira da Foz, algumas inundações ocorreram também em Lavos, Vila Verde e Alqueidão.

Em síntese, nos dias 27 a 29 de Janeiro de 2001, os diques do Baixo Mondego romperam em 14 sítios - no Canal Principal, sobretudo na margem esquerda, e no Leito Periférico Direito (Montemor-o-Velho) provocando transbordo com a formação de lóbulos de derrame (foto 14) e rápido alagamento dos campos. Note-se que nos menores caudais de cheia ocorridos a 6-8 de Dezembro 2000 e a 6 de Janeiro 2001 vários diques ficaramdanificados e não tinham sido entretanto reparados na totalidade. Os lóbulos de derrame eram

(i) Também se provocou rebentamento artificial de um dique, para facilitar o escoamento da planície para o canal, em Formoselha. Em Lares, a última grande cheia ocorreu em 1966, em que se registou nível um pouco superior. constituídos por areãoe areias cascalhentas, sedimentos que anteriormente ao transbordo estavam a ser transportados ao longo do leito; nas planícies alagadas ocorreu lenta decantação de silte e argila. Os principais derrames sedimentares ocorreram nos locais a seguir descritos, de montante para jusante: a) dique fusível $n^{\circ} 1$, margem direita, Choupal, volume de areia não estimado; $b$ ) rupturas do dique em Ribeira de Frades, margem esquerda, um volume de cerca de $50 \times 10^{3}$ $\mathrm{m}^{3} ; \mathrm{c}$ ) dique fusível $\mathrm{n}^{\circ} 3$, margem direita, a sul de $\mathrm{S}$. João do Campo, aproximadamente $12 \times 10^{3} \mathrm{~m}^{3} ; \mathrm{d}$ ) dique fusível $n^{\circ} 4$, margem direita, a sul de $S$. Martinho de Árvore, cerca de $12 \times 10^{3} \mathrm{~m}^{3}$; e) ruptura no dique em Santo Varão, margem direita, da ordem de $45 \times 10^{3}$ $\mathrm{m}^{3}$; f) ruptura entre Arzila e Pereira, margem esquerda, volume de areia não estimado.

As principais localidades isoladas foram Ribeira de Frades, Casais do Campo, Pereira do Campo, Santo Varão, Formoselha e, mais tarde, Montemor-o-Velho, Ereira e Lares. Localmente, verificou-se subida do nível de água até $3 \mathrm{~m}$.

Escoamentos importantes fora do Canal Principal doMondego verificaram-se nos locais a seguir descritos, de montante para jusante:

1) A partir do descarregador de cheia $n^{\circ} 1$, com cerca de $200 \mathrm{~m}^{3} / \mathrm{s}$, rebentando com o pontão do Choupal e atravessando para NW (segundo o Rio Velho) o alagado Campo do Bolão e introduzindo-se em grande parte no Leito Periférico Direito, que junto da Mata da Geria não possui diques longitudinais. Com este aumento de descarga neste Periférico, que praticamente só devia estar a recebercaudal significativo da Vala de Ançã, arrancou-se e arrastou-se muita vegetação deste leito o que terá contribuído para a obstrução do escoamento através dos pilares da ponte das Lavandeiras, levando à sua destruição e à ruptura do dique na margem direita (inundação de Montemor-o-Velho). Note-se que o fusível $\mathrm{n}^{\mathrm{o}} 2$ funcionou mal (dos $150 \mathrm{~m}^{3} / \mathrm{s}$ projectados, descarregou menos de $50 \mathrm{~m}^{3} / \mathrm{s}$ ), o que evitou a erosão do talude oriental da auto-estrada A1 pois esta estrutura rodoviária foi localizada no sector adjacente a jusante e não possui conveniente protecção contra este risco.

2) A partir das rupturas no dique esquerdo, junto a Ribeira de Frades e Arzila, seguindo pela margem esquerda da planície aluvial e introduzindo-se no Leito Periférico Esquerdo (e inundando as povoações a sul) originou o seu rebentamento junto da confluência com a Vala de Arzila e com o Canal Principal do Mondego.

3) A partir da ruptura no dique direito, junto a Santo Varão, na direcção WSW ao longo do antigo leito do rio até se introduzir no Leito Periférico Direito, através da ruptura artificial deste.

4) A partir da ruptura no dique direito do Leito Periférico Direito, junto a Montemor-o-Velho, na 
direcção WSW ao longo do antigo leito até atingir a confluência do Foja e mesmo, progredindo um pouco mais para jusante, até atingir Lares. Cerca de $3 \mathrm{~km}$ do talude norte do IP3 ruiu em Santa Eulália. A jusante da Estação Elevatória de Foja o C.C.G. ("canal de rega") ficou danificado numa extensão de $600 \mathrm{~m}$, o que também já tinha sucedido em Santo Varão e, parcialmente, noutros locais a montante (fotos 1 e 2), tornando inoperacional a ETA de Vila Verde que era a principal fonte de água potável ao concelho de Figueira da Foz.

Nos sectores intermédio e distal do estuário, situados aproximadamente para jusante da bifurcação dos braços que envolvem a Ilha da Morraceira, não ocorreu transbordo do canal do Mondego para as margens, mesmo quando os picos de caudal atingiram $1942 \mathrm{~m}^{3} / \mathrm{s}$ em Coimbra, a que terão correspondido cerca de $1980 \mathrm{~m}^{3} / \mathrm{s}$ em Montemor-o-Velho; $2280 \mathrm{~m}^{3} / \mathrm{s}$ na confluência do Foja e cerca de $2390 \mathrm{~m}^{3} / \mathrm{s}$ na foz (RODRIGUES et al., 2001). Este facto deve explicarse pelas muitas rupturas dos diques a montante terem deixado escapar grande parte do caudal para a planície aluvial, diminuindo a ponta de cheia na foz, e também em virtude de o Braço Norte ter sido, recentemente, muito aprofundado por dragagem (CUNHA \& MENDES, 2000), o que contribuiu para um eficaz escoamento da descarga fluvial mesmo em maré enchente.

\section{Características das águas estuarinas em situação de cheia}

Com baixos e moderados caudais de descarga fluvial o Braço Norte do Mondego apresenta águas salinas e correntes alternantes de fluxo e refluxo (DINIS \& CUNHA, 1999). Mas nas raras situações de cheia a velocidade da corrente é muito elevada, sempre para jusante e sem salinidade, mesmo durante a maré enchente.

No Braço Norte, na zona entre o Cais Comercial e a ponte da Figueira da Foz, na campanha de registo realizada no dia 31 de Janeiro de 2001 (Tab. 2), em contexto de enfraquecimento do caudal de cheia (pois já sóchegavam $570 \mathrm{~m}^{3} / \mathrm{s}$ a Coimbra) a velocidade máxima (em vazante) à superfície foi de $2,0 \mathrm{~m} / \mathrm{s}$ e no fundo cerca de $1,5 \mathrm{~m} / \mathrm{s}$ (o que permite arrastar grãos de dimensão inferior a $3 \mathrm{~mm}$ ); a velocidade incrementava ligeiramente para montante. Com tão forte descarga fluvial, a maré enchente praticamente não induzia variação na condutividade (100 $\mu$ mhos à superfície e $110 \mu$ mhos no fundo), mas provocava redução da velocidade $(1,8 \mathrm{~m} / \mathrm{s}$ à superfície e $0,9 \mathrm{~m} / \mathrm{s}$ no fundo, com $3 \mathrm{~h}$ de enchente).

A quantidade de material em suspensão atingiu o seu máximo no dia 28 de Janeiro de 2001 , no seguimento da ponta de cheia ocorrida durante a noite; geralmente a argila $(<4 \mu \mathrm{m})$ era mais abundante que o silte (4-63 $\mu \mathrm{m})$. Em anteriores campanhas efectuadas sob fracos e moderados caudais, o registo de sólidos em suspensão foi sempre inferior a 0,1 g/l (CUNHA et $a l ., 1997 \mathrm{a}$; DINIS \& CUNHA, 1999).

\section{Risco de inundação e Ordenamento do terri- tório}

Na bacia hidrográfica do Mondego, a grande irregularidade da precipitação anual devido às condições climáticas mediterrâneas e o regime torrencial favorecido pelas características montanhosas do sector mais a montante da bacia hidrográfica, induzem a ocorrência de elevados caudais fluviais de difícil previsão e regularização por forma a serem evitados os efeitos negativos das cheias (F. REBELO, 2001). Uma incorrecta gestão dos recursos hídricos não pode ser ilibada de responsabilidades através da desculpa por "Causas naturais imprevisíveis", pois as características da bacia hidrográfica já são suficientemente conhecidas e estão também quantificadas as prudentes necessidades de armazenamento $e$ as inerentes consequências em função de pontas de cheias com diversas magnitudes.

A precoce consciência da importância da delimitação das zonas inundadas no Baixo Mondego pelas maiores cheias levou à execução de cartografia na escala $1 / 50.000$, considerada fundamental a um correcto ordenamento do território (FOLQUE \& SILVA, 1858; Fig. 5).

Antes do Inverno de 2000/2001, por ocasião de um Seminário dedicado aos Planos de Bacia Hidrográfica (1999) criticámos publicamente e posteriormente publicámos em livro (CUNHA \& DINIS, 2000, p. 41) diversas insuficiências do PBHM, das quais, pela oportunidade, a seguir se transcreve o parágrafo sobre o risco de inundação na Bacia do Mondego:

Tab. 2 - Características das águas estuarinas no Braço Norte do rio Mondego, na zona entre

o Cais Comercial e a ponte da Figueira da

Foz, bem como os respectivos caudais a

montante (Açude de Coimbra) na cheia de princípios de 2001

\begin{tabular}{|c|c|c|c|c|c|}
\hline Dia de 2001 & $\begin{array}{c}\text { Caudal em } \\
\text { Coimbra }\left(\mathrm{m}^{3} / \mathrm{s}\right)\end{array}$ & $\begin{array}{c}\text { Velocidade máxima } \\
\text { à superficie }\end{array}$ & $\begin{array}{c}\text { Velocidade } \\
\text { máxima no fundo }\end{array}$ & $\begin{array}{c}\text { Material em } \\
\text { suspensão }(\mathrm{g} / \mathrm{l})\end{array}$ & $\begin{array}{c}\text { Salinidade } \\
\%\end{array}$ \\
\hline 27 Jan. (tarde) & 1700 & - & - & 0,6 & 0,00 \\
\hline 28 Jan. (manhã) & $1900 \mathrm{a} 1600$ & - & - & 8,9 & 0,00 \\
\hline 31 Janeiro & 570 & $2,0 \mathrm{~m} / \mathrm{s}$ & $1,5 \mathrm{~m} / \mathrm{s}$ & $0,2 \mathrm{a} 0,5$ & 0,00 \\
\hline 3 Fevereiro & 500 & $1,0 \mathrm{~m} / \mathrm{s}$ & - & - & 0,00 \\
\hline
\end{tabular}




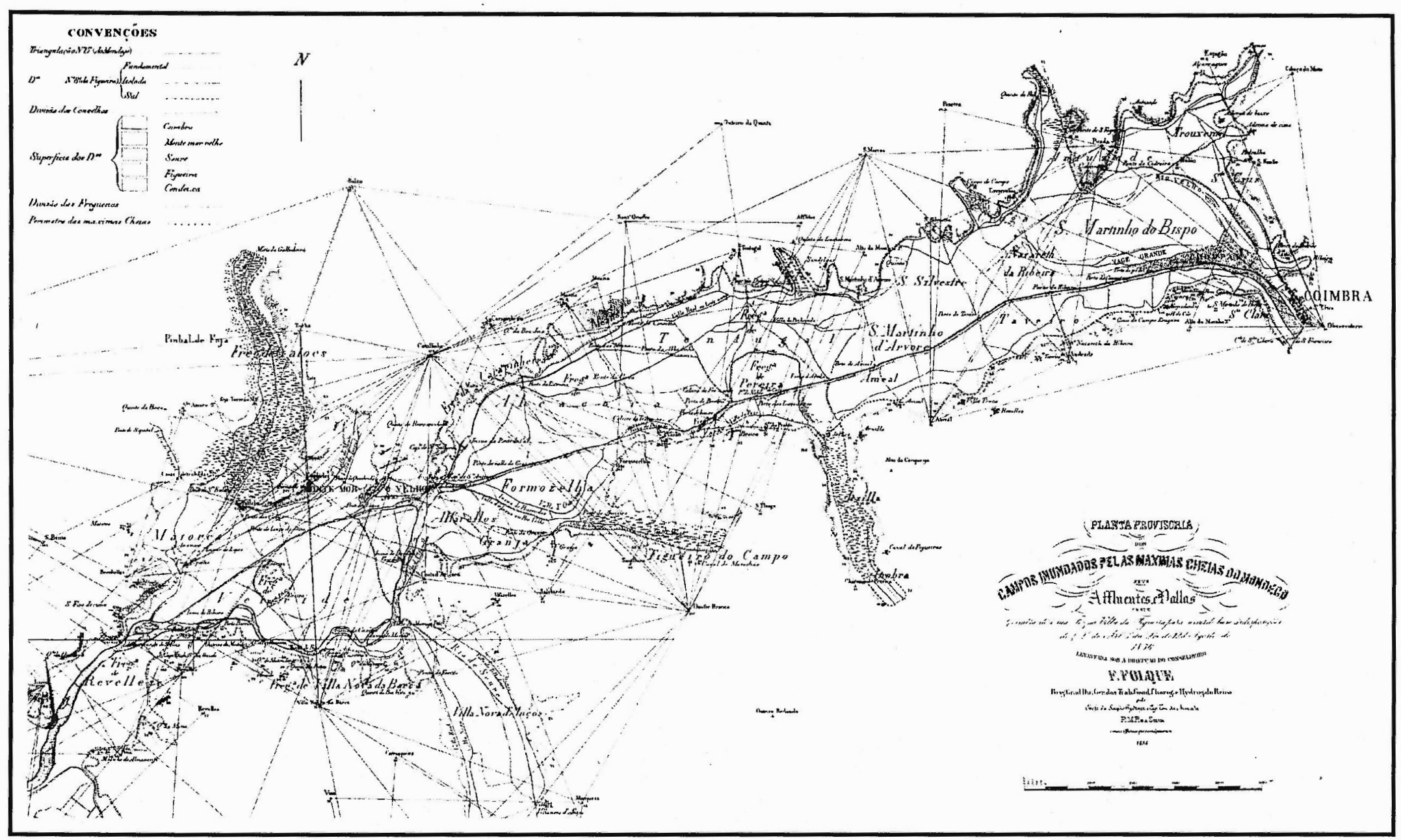

Fig. 5 - Reprodução parcial do sector oriental e central da carta das zonas inundadas pelas maiores cheias do Mondego, na escala 1/50.000 (adaptada de Folque \& Silva, 1858). Esta carta permite observar como era o sistema fluvial anteriormente às obras de regularização fluvial que determinaram a configuração actual (comparar com a figura 2). 
"Não existem, nem parecem estar previstas, pormenorizadas cartas de zonamentos de usos face ao risco de inundação. Deveriam ser analisadas as localizações de infra-estruturas (acessos viários, etc.) e equipamentos sensíveis a este risco. Também deveria merecer discussão a forma de avaliação dos leitos de inundação. Note-se que o regime hidrológico nesta bacia é muito irregular e que os registos de caudais não são suficientes para uma desejável estimativa dos caudais de cheia para períodos de retorno superiores a 100 anos. Por precaução, devem ser também tidos em conta no planeamento as possibilidades de mau funcionamento, ou mesmo falha, do actual sistema de controle de cheias. Note-se que, em caso extremo, existe sempre o risco de ruptura das albufeiras (por exemplo, a da Aguieira), que também devia ser tido em conta em termos de previdente ordenamento das ocupações antrópicas."

Relativamente ao referido Plano de Bacia Hidrográfica do Mondego, que quando o criticámos (1999) se encontrava ainda na fase 1 - Análise e diagnóstico da situação de referência - e que depois foi aprovado, fica-se com a ideia de que pouco terá servido para evitar as seguintes cheias do Mondego.

A regularização do caudal do Mondego evitou as habituais cheias no Baixo Mondego, mas também induziu uma imprevidente ocupação da planície aluvial por construções, que ficam expostas em risco quando ocorrem caudais mais elevados do que os de dimensionamento da obra hidráulica, correspondendo a um caudal de $1200 \mathrm{~m}^{3} / \mathrm{s}$ em Coimbra e de $2955 \mathrm{~m}^{3} / \mathrm{s}$ no troço final do estuário. Em caso de superior caudal afluente a Coimbra existem dispositivos de emergência - quatro diques fusíveis localizados na margem direita do Canal Principal - que, em conjunto, poderiam descarregar para os campos ate $800 \mathrm{~m}^{3} / \mathrm{s}$; contudo, nestas cheias, alguns sistemas de descarga não funcionaram e o aumento de caudal levou ao galgamento dos diques, favorecido por insuficiente manutenção da obra hidráulica. Na primeira cheia também se comprovaram assentamentos em algumas zonas do dique esquerdo do CPM imediatamente a montante da ponte de Casais, atingindo $0,7 \mathrm{~m}$ abaixo do definidoem projecto, que foram na altura reparados provisoriamente (Eng. Ferreira dos Santos, informação oral, 2001). É defendido que na terceira cheia a primeira ruptura do dique da margem esquerda (Rib. Frades) se deveu por fragilização local da estrutura pelas águas de escorrência da auto-estrada $\mathrm{A} 1$, pois a ruptura ocorreu cerca da 1 h do dia 27 , numa fase em que a descarga da Aguieira era de $515 \mathrm{~m}^{3} / \mathrm{s}$ e que se manteve até cerca das $9 \mathrm{~h}$ do mesmo dia.

Ao que parece, o colapso da obra hidráulica a jusante de Coimbra ocorreu antes da última cheia.
Isto é, ter-se-á dado pela elevada frequência de altos caudais, durante um longo tempo (a última década). No entanto, importa dizer que as três pontas de cheia do Inverno de 2000/2001 se sucederam ao longo de um período de cerca de dois meses, durante o qual o nível da Aguieira nunca baixou o suficiente para permitir o encaixe da maior ponta (a de finais de Janeiro de 2001).

Quanto à grande ruptura no dique em Santo Varão (fotos 2 e 14), a sua localização pode ser explicada pela concertação de dois factores: 1) situar-se na concavidade do primeiro meandro significativo no Canal Principal; 2) existirem barras de meandro, que um alto fluxo de cheia tem dificuldade em contornar.

Para além da necessidade de uma eficaz gestão e manutenção das obras hidráulicas do Mondego é também crucial um previdente ordenamento do território que evite a ocupação urbana e industrial da planície aluvial, devido à probabilidade de ocorrerem maiores caudais de cheia, mais raros que os de periodicidade centenária, que podem provocar a destruição da obra hidráulica e causar efeitos muito mais dramáticos às populações ribeirinhas. Como consequência das cheias que em 2001 atingiram a cota $21 \mathrm{~m}$ nas margens do Mondego, em Coimbra, decidiu-se alterar o projecto de construção em leito de cheia no âmbito do Programa Polis, evitando, agora, as cotas mais baixas e recorrendo a aterros.

Nas obras que, de Março a Dezembro de 2001, o INAG mandou proceder no Baixo Mondego, foram construídas "soleiras de fixação"(foto 16) no Canal Principal do Mondego, que constavam do projecto inicial.

No dia 5 de Dezembro de 2001 o INAG realizou uma cerimónia em que divulgou o estado das obras de recuperação das estruturas hidráulicas afectadas pelas cheias no Baixo Mondego, e que o Governo iria gastar quase 3,5 milhões de contos durante três anos, essencialmente para pagar estas reparações e os restantes cerca de 400 mil contos num programa de vigilância e manutenção das infra-estruturas.

\section{Conclusões}

Relativamente à avaliação da excepcionalidade dos fenómenos meteorológicos na génese destas cheias, tendo em conta o conjunto da área da bacia hidrográfica do Mondego, a precipitação atmosférica verificada no Inverno de 2000/2001, expressa quer pela totalização para o máximo mensal, quer para o 
conjunto dos meses de Dezembro de 2000 e Janeiro de 2001 , quer ainda para o valor máximo em $24 \mathrm{~h}$, não assume um período de retorno superior ao centenário. Assim, se não existisse qualquer controlo de caudais, as condições naturais deste Inverno teriam originado em Coimbra uma cheia de excepcionalidade quase centenária. Portanto, os quantitativos de precipitação registados neste Inverno não justificam as cheias verificadas em regime regularizado por obras de elevado custo (em menos de 30 anos foram gastos 130 milhões de contos - cerca de 650 milhões de euros).

Efectivamente, não têm sido cumpridas as recomendações de projecto em termos da cota máxima de exploração da Barragem da Agueira durante o período de Inverno, com as inerentes consequências na capacidade de amortecimento dos picos de cheia afluentes a Coimbra. Assim, nos últimos doze anos, por cinco vezes se registaram em Coimbra caudais que sódeveriam ocorrer com uma frequência centenária se existisse uma gestão das obras hidráulicas de acordo com o preconizado em projecto; daqui resulta um maior desgaste das estruturas hidráulicas do Baixo Mondego e um maior risco de inundação (maior frequência e magnitude).

No Inverno analisado foi insuficiente o amortecimento das pontas de cheias feito pelas barragens de Aguieira-Fronhas. A ponta de cheia de 27-29 de Janeiro de 2001 teria atingido em Coimbra: a) um caudal de $2800 \mathrm{~m}^{3} / \mathrm{s}$, na ausência de controlo por barragens; b) um caudal inferior a $1200 \mathrm{~m}^{3} / \mathrm{s}$, cumprindo com os procedimentos especificados pelo projectista para a gestão da barragem. A realidade mostrou que o controlo humano levou a que se atingisse o limiar de ruptura da obra hidráulica do Baixo Mondego $\left(2000 \mathrm{~m}^{3} / \mathrm{s}\right)$.

Os diques do Canal Principal romperam sob caudais inferiores aos definidos em projecto, o que pode ser explicado pela:

- Progressiva debilitação devidoà grande frequência de elevados caudais.

- Existência do "açude" de Formoselha, que tinha promovido significativo assoreamento a montante (com árvores no leito !), o que terá favorecido os galgamentos no troço Casais-Formoselha durante as cheias.

- Inadequada manutenção das estruturas hidráulicas, nomeadamente dos diques e da capacidade de escoamento dos canais;

As rupturas nos diques do Canal Principal concentraram-se no troço entre Casais e Formoselha, que estavam muito assoreados e com árvores no leito; portanto, nestas condições, o canal não tinha a capacidade máxima de escoamento dimensionada pelo projecto $\left(1200 \mathrm{~m}^{3} / \mathrm{s}\right)$. Estas reduções locais da secção útil do canal provocaram o galgamento consequente ruptura dos diques. Consideramos que o maior assoreamento deste troço resulta da existência do "açude" de Formoselha e de outros "açudes" mais pequenos, apontando neste sentido a coincidência das rupturas com a localização destas barreiras no leito. Consequentemente, somos de parecer que a recente alteração na geometria do Canal Principal relativamente ao projecto inicial, constituída pela implantação de 11 secções com esporões transversais ao leito (designados por soleiras de fixação), no troço entre o Açude de Coimbra e a confluência com o Canal Periférico Esquerdo, implicará um aumento do risco de galgamento dos diques longitudinais quando ocorram caudais de cheia, pelo que não deve ser continuada a sua implantação para jusante e deverá ser tecnicamente fundamentada a ponderação das vantagens versus inconvenientes dos já instalados.

Com as obras de controlode cheias e aproveitamento hidráulico, nas últimas décadas o Baixo Mondego deixou de ter as habituais inundações o que induziu a uma imprevidente ocupação da planície aluvial por habitações e estruturas industriais. Algumas destas construções em áreas comrisco de inundação resultam da falta de esclarecimento das populações e de insuficiente fiscalização por parte das entidades competentes, mas outras construções em áreas de risco são da responsabilidade directa do próprio Estado, como é o caso da ETAR de Ribeira de Frades ou o Quartel dos Bombeiros de Montemor-o-Velho que foram inundados.

\section{Agradecimentos:}

Consideramos muito importantes os esclarecimentos prestados pelo Eng. Ferreira dos Santos (ABOFHBM), Eng. Carlos Batista (INAG) e pelo Eng. Idálio Reis (IHERA) que também disponibilizou uma imagem de localização dos danos nas estruturas hidráulicas do Baixo Mondego (parcialmente reproduzida nas fotos 1,2 e 3 ).

Agradecemos ainda: ao INAG a disponibilização de valores de caudais; ao Eng. Mota Lopes (DRAOT-Centro) e ao Sr. António Carriço (Director da ABOFHBM), que disponibilizaram fotografias aéreas do Baixo Mondego; ao Lic. João Mendes (FCTUC) a colaboração em diversas tarefas de investigação, à Lic. Ana Andrade (DCT-UC) o acompanhamento nos reconhecimentos de campo e apoio na redacção do texto, aos colegas e alunos que colaboraram na campanha de monitorização hidrodinâmica da cheia, 
ao Lic. Rui Batista pela ajuda no desenho de figuras. Finalmente, deve-se ao Prof. J. Antunes do Carmo (DEC-UC) a leitura crítica da versão preliminar e as sugestões de melhorias.

\section{Referências bibliográficas}

Cunha, P. Proença (2001a) - Efeitos das cheias de Janeiro de 2001 no estuário do Mondego. VIII Encontro sobre Riscos Naturais (Resumos), 19 de Outubro de 2001, Universidade de Coimbra, $1 \mathrm{p}$.

Cinnha, P. Proença (2001b) - As cheias do Mondego no inverno de 2000/2001. Encontro sobre Riscos Naturais: Aprender com 2001 (Resumos), 26 de Outubro de 2001, Universidade do Porto, $1 \mathrm{p}$.

Cunha, P. Proença \& Dinis, J. L. (2000) - O Estuário do Mondego no Plano de Bacia Hidrográfica - aspectos sedimentares e ambientais. In: Os estuários de Portugal e os Planos de Bacia Hidrográfica. Associação Eurocoast-Portugal (Ed.), pp. 35-43.

Cunha, P. Proença \& Dinis, J. L. (2002) - Sedimentary dynamics of the Mondego estuary. In Pardal M. A., Marques J. C. \& Graça M. A. S. (editors) Aquatic ecology of the Mondego river basin. Global importance of local experience. Chapter 1.4: 43-62, Imprensa da Universidade, Coimbra.

Cunha, P. Proença; Dinis, J. L. \& Reis, R. Pena dos (1997a) Relatório Final do projecto de investigação PEAM/C/GEN/ 1247/93 (Programa Específico para o Ambiente - JNICT/ (DGA): "Avaliação das modificações antrópicas actuais nos sub-ambientes sedimentares do estuário do Mondego". Faculdade de Ciências e Tecnologia da Univ. de Coimbra, 152 p. e 8 anexos.

Cunha, P. Proença \& Mendes, J. Almeida (2000) - Análise das dragagens no Porto da Figueira da Foz (Estuário do Mondego). In: Perspectivas de gestāo integrada de ambientes costeiros, Associação Eurocoast-Portugal (Editor), Porto,15 p.

Cunha, P. Proença; Pinto, J. \& Dinis, J. L. (1997b) - Evolução da fisiografia e ocupação antrópica na área estuarina do Rio Mondego e região envolvente (Portugal centro-oeste), desde 1947. Territorium, Coimbra, 4, pp. 99-124.

D.G.R.A.H. (1987) - Aproveitamento do Vale do Mondego.

Dinis, J. L. \& Cunha, P. Proença (1999) - Sedimentologia e hidrodinâmica dos subsistemas estuarinos do Mondego (Portugal central). Recursos Hídricos, Revista da Associação Portuguesa dos Recursos Hídricos, vol. 20, n 1, pp. 37-50.
Folque, F. \& SilvA, F. M. P. (1858) - Planta provisoria dos campos inundados pelas maximas cheias do Mondego, seus affluentes e vallas, desde Coimbra ate a sua Foz na Villa da Figueira para servir de base às disposições do n. 2 do Art. 3 da Lei de 12 de Agosto de 1856. Carta na escala 1/50.000.

GANHO, N. (2001) - O "paroxismo" pluviométrico de 2000/2001 em Coimbra. Umas notas a montante dos riscos naturais e da crise. VIIIEncontro sobre Riscos Naturais (Resumos), 19 de Outubro de 2001, Universidade de Coimbra, 1 p.

Lencastre, A. \& Franco, F. M. (1984) - Lições de Hidrologia. Universidade Nova de Lisboa (Ed.), 451 p.

Lima, M. I. Pedroso de \& Lima, J. M. Pedroso de (2002) - Precipitation and the hydrology of the Mondego catchment: a scaleinvariant study. In Pardal M. A., Marques J. C. \& Graça M. A. $\mathrm{S}$. (editors) Aquatic ecology of the Mondego river basin. Glabal importance of local experience. Chapter 1.4: 13-28, Imprensa da Universidade, Coimbra.

Marques, J. C.; Graça, M. A. \& PARdal, M. A. (2002) - Introducing the Mondego river basin. In Pardal M. A., Marques J. C. \& Graça M. A.S. (editors) Aquatic ecology of the Mondegoriver basin. Global importance of local experience. Chapter 1.4: 7-12, Imprensa da Universidade, Coimbra.

Martins, A. F. (1940) - O esforço do Homem na Bacia do Mondego. Coimbra, Ed. Autor, 299 p.

PBHM (1999) - Plano de Bacia Hidrográfica do Mondego, vol. 1 e anexos.

Rebelo, F. (2001) - Riscos Naturais e Acção Antrópica. Coimbra, Imprensa da Universidade, $274 \mathrm{p}$.

Rodrigues, R.; Brandāo, C. \& Costa, J. Pintoda (2001) - Hidrologia das cheias do Mondego de 26 e 27 de Janeiro de 2001. Instituto da Água - Direcção dos Serviços de Recursos Hídricos, 13 p. http://www.inag.pt/snirh/actual/ultimas/cheias_mondego. .html

SANCHEs, R. (1996) - O problema secular do Mondego e a sua resolução. Lab. Nac. de Engenharia Civil (Ed.), Lisboa, 208 p.

Santos, F. SEABra (Coordenador) et al. (2001) - Relatório Final do Grupo de Trabalho para a análise das cheias no BaixoMondego no Inverno de 2000/2001. Ordem dos Engenheiros - Região Centro e Departamento de Engenharia Civil FCTUC, 5 p.

VELoso, A. SANTos (2001) - Comunicação oral no Seminário sobre "O esforço do Homem na bacia do Mondego - Encanto ou desencanto?", Fac. Direito da Univ. Coimbra, Março de 2001. 


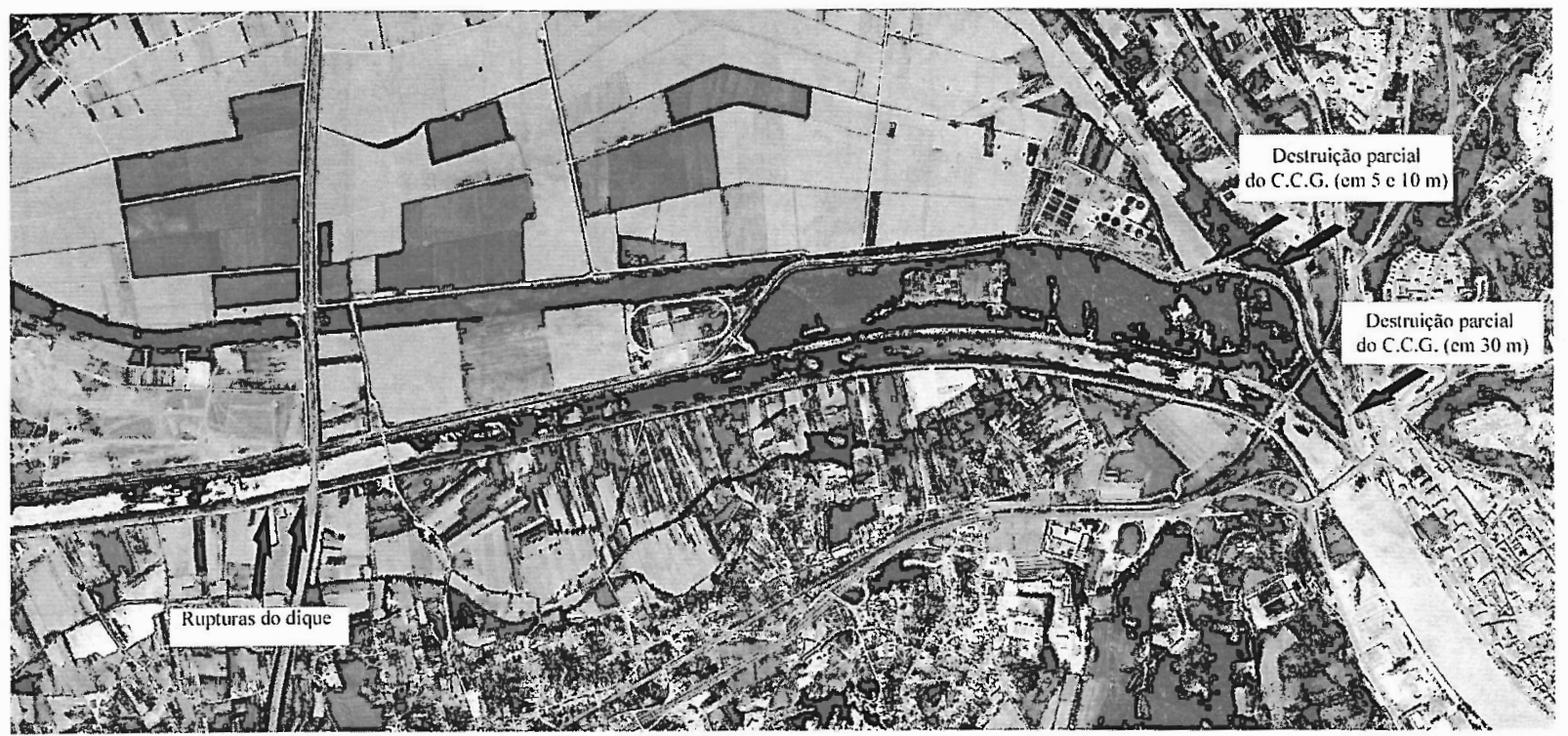

Foto 1 - Localização dos estragos nas estruturas hidráulicas entre Coimbra e a Ribeira de Frades (adap. a partir de ortofoto do CNIG de 1995). Junto ao Choupal ocorreu destruição de dois troços do Canal Condutor Geral; situam-se duas rupturas no dique em Ribeira de Frades, junto a uma quinta agrícola e à auto-estrada Al.

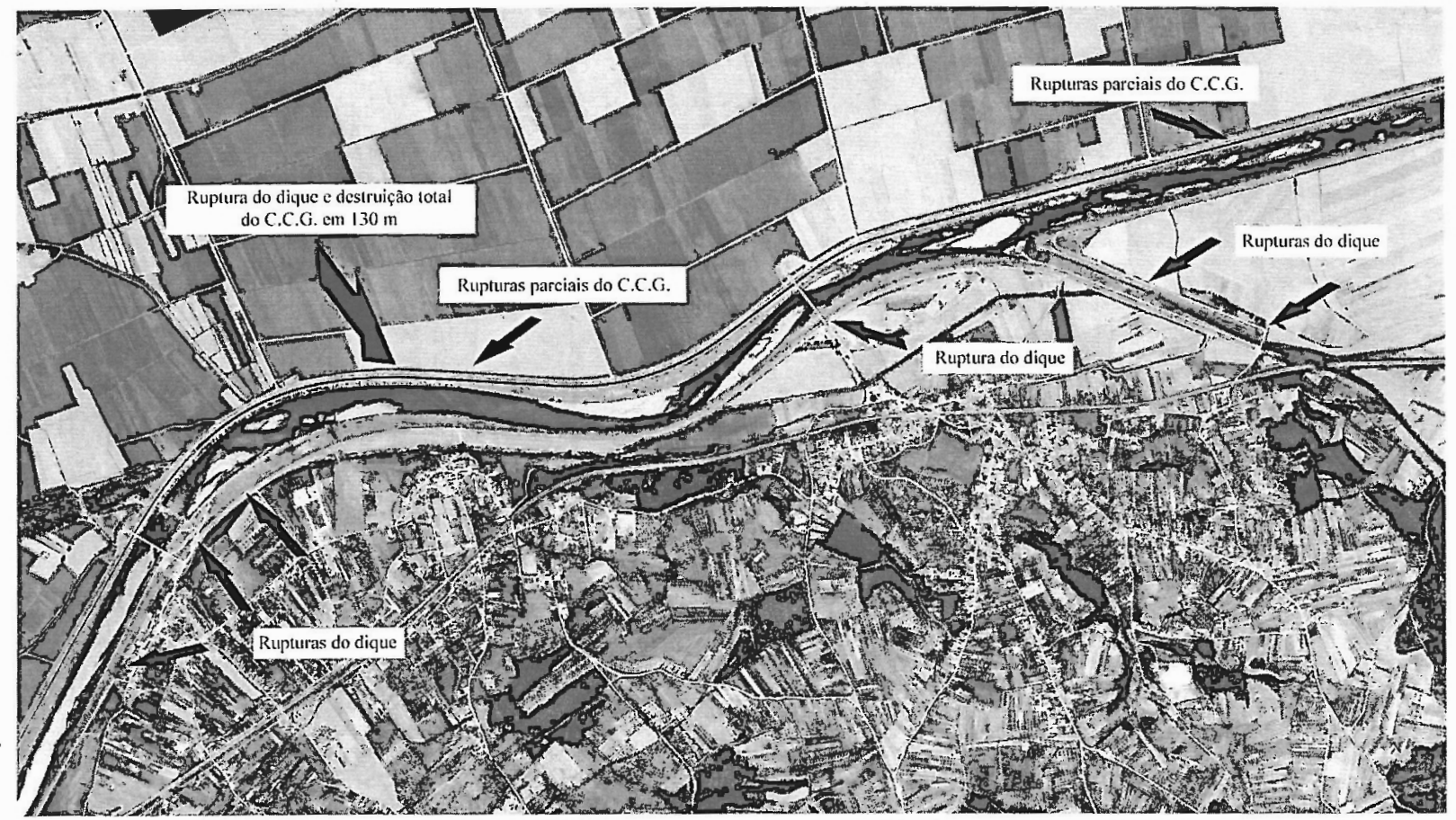

Foto 2 - Localização dos estragos nas estruturas hidráulicas no Canal Principal do Mondego, entre a confluência com o Leito Periférico Esquerdo e o açude de Formoselha (adap. a partir de ortofoto do CNIG, 1995). Observa-se o grande assoreamento a montante do açude de Formoselha (a cor clara a jusante corresponde apenas a reflexão da luz na água) e entende-se a localização da grande ruptura do dique direito $(130 \mathrm{~m})$, junto a Santo Varăo, pela dificuldade em um elevado fluxo conseguir contornar umas desenvolvidas barras de meandro. 


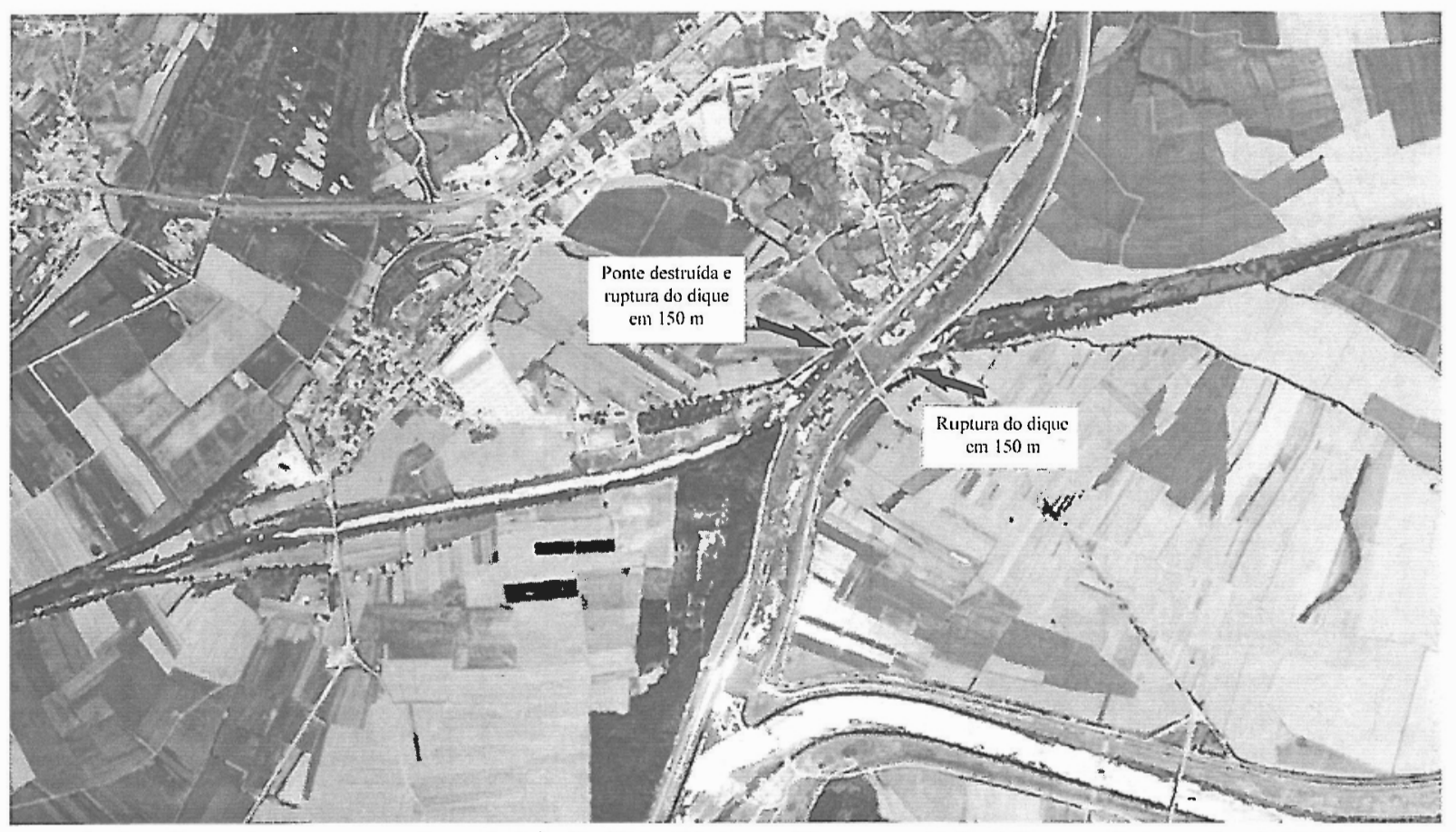

Foto 3 - Localização das rupturas nos diques do Leito Periférico Direito, em Montemor-o-Velho (adap. a partir de ortofoto do CNIG, 1995).

No mesmo sítio consegue-se visualizar a ponte das Lavandeiras. Para além da obstrução ao escoamento que deve ter sido promovida pelos pilares desta ponte, a ruptura no dique direito também se explica pela tendência natural em um fluxo de cheia retomar o anterior leito. No canto inferior da imagem observa-se a confluência do LPD com o Canal Principal do Mondego (este com cor clara devido a reflexão da luz na água).

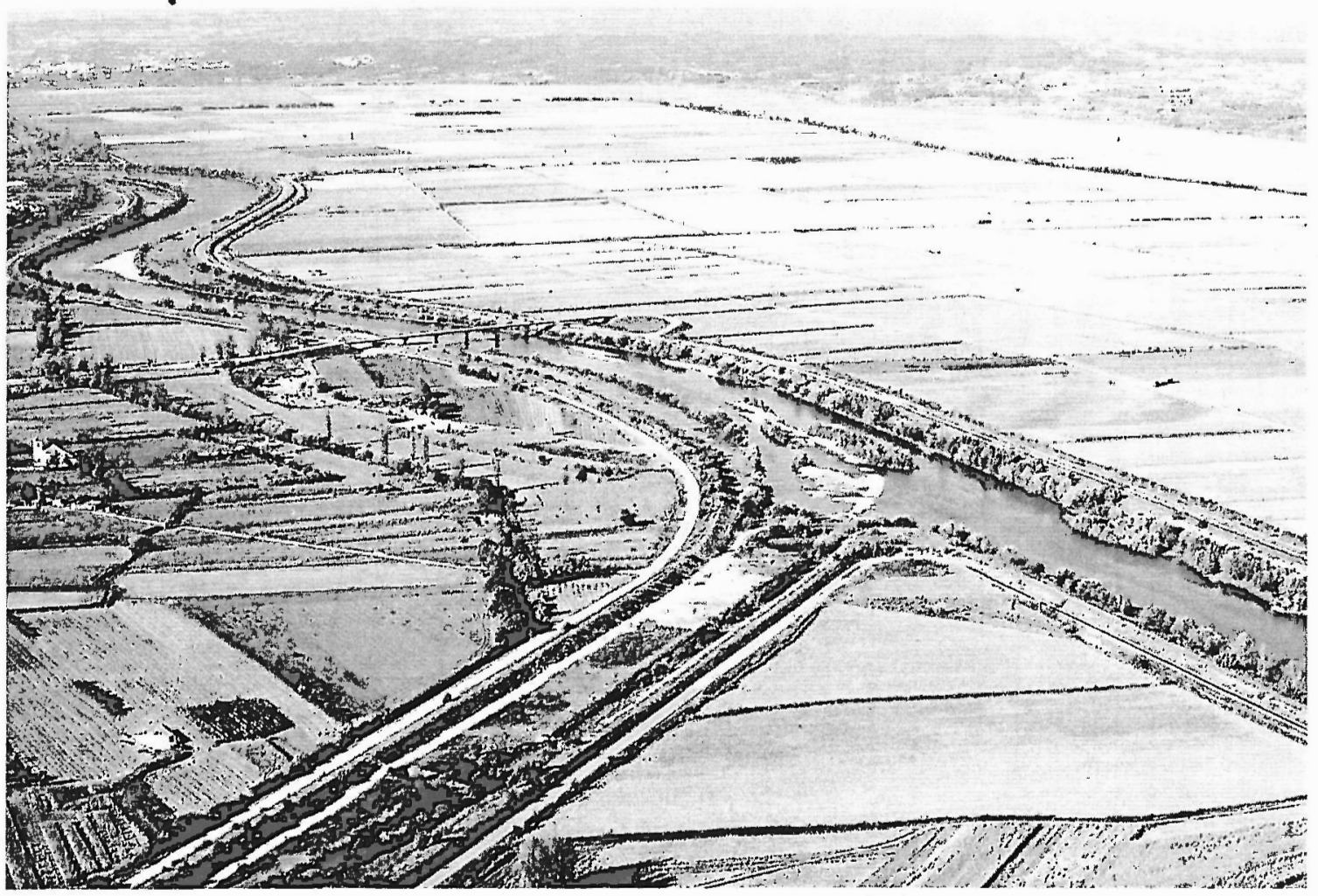

Foto 4 - Vista aérea oblíqua do Canal Principal do Mondego, entre a confluência com o Leito Periférico Esquerdo e o açude de Formoselha (foto de P. Cunha, a 6/11/1998). Notar as ilhas com árvores no local onde se fazia extracção de areia. 


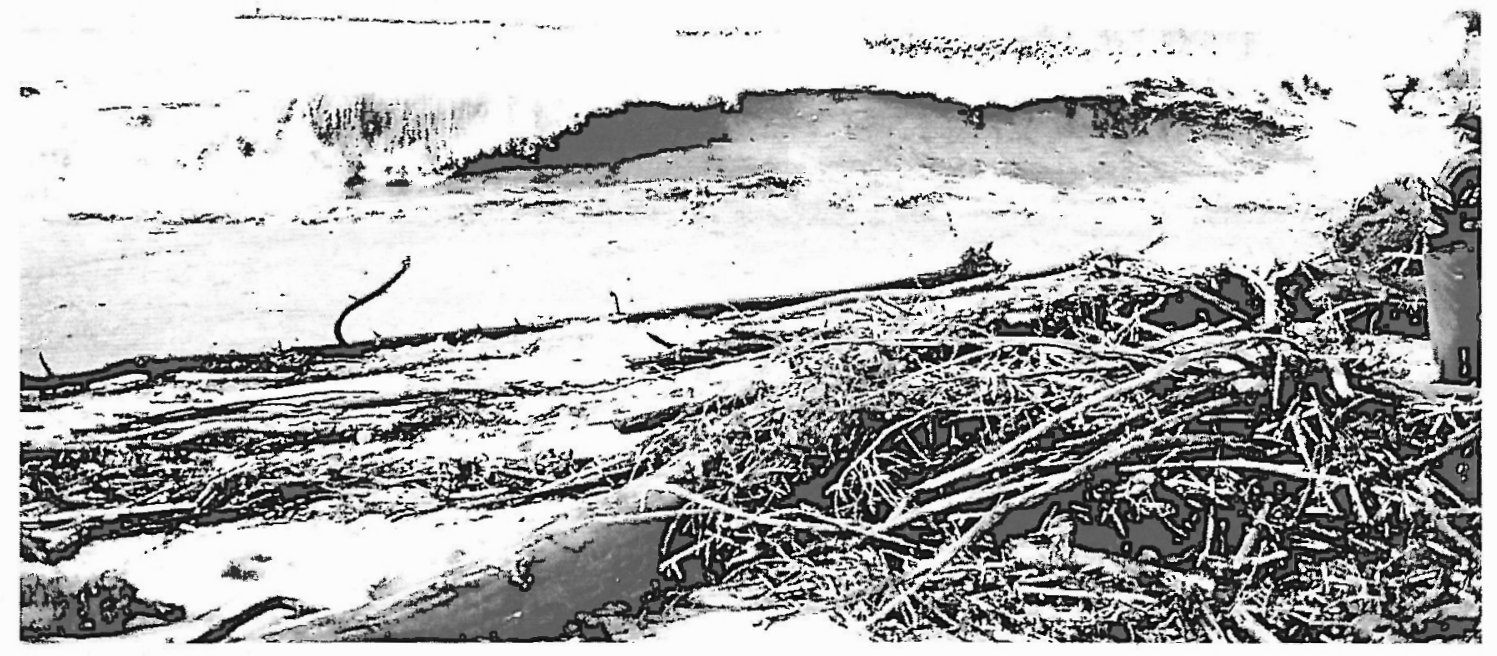

Foto 5 - Abundantes materiais trazidos por flutuação pelo Mondego, dispersos pelas praias (foto de P. Cunha, a 8/12/2000).

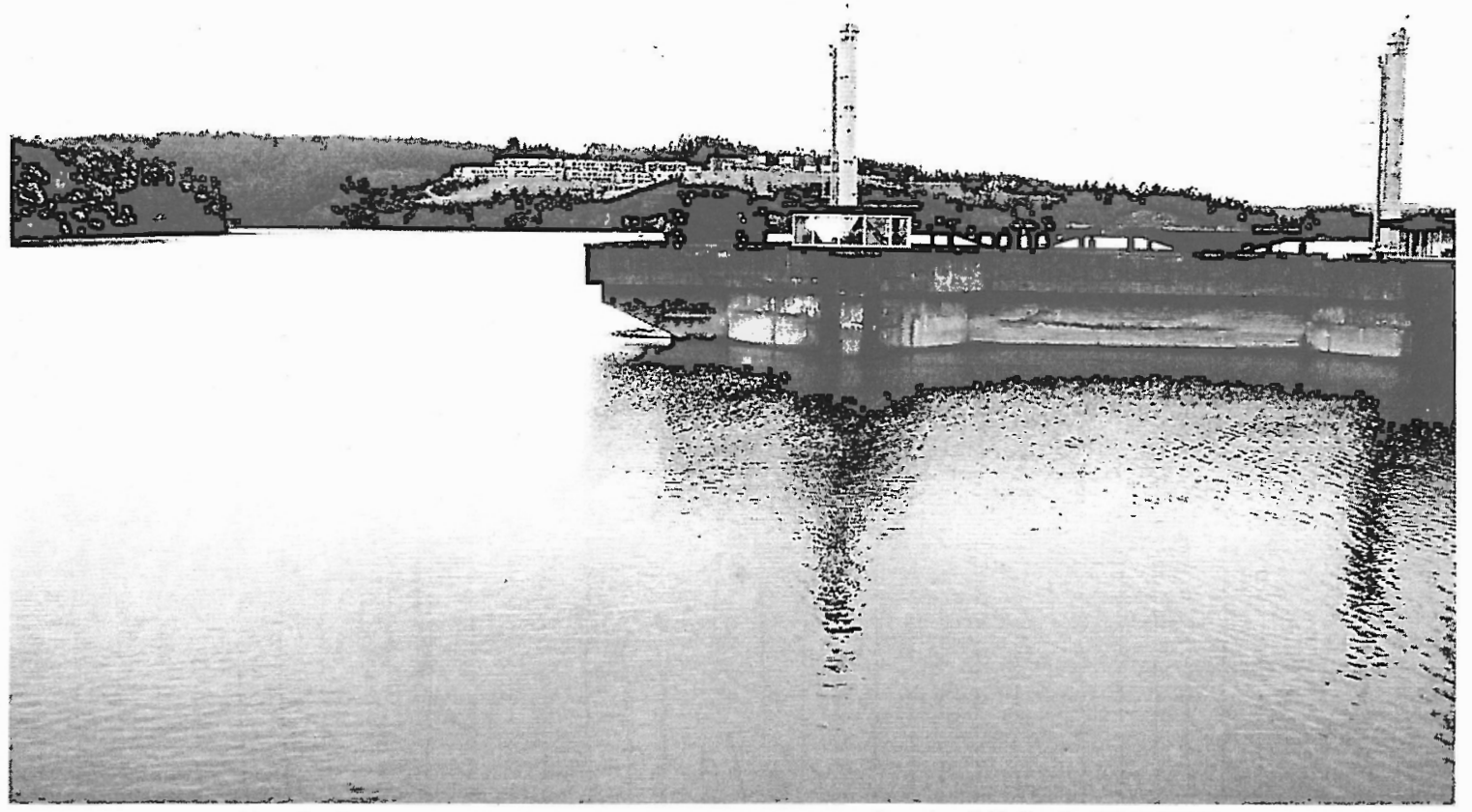

Foto 6 - Aspecto da albufeira da Aguieira (foto de M. Morais, pelas $17 \mathrm{~h}$ do dia 27/0I/2001). 
territorium 9.2002

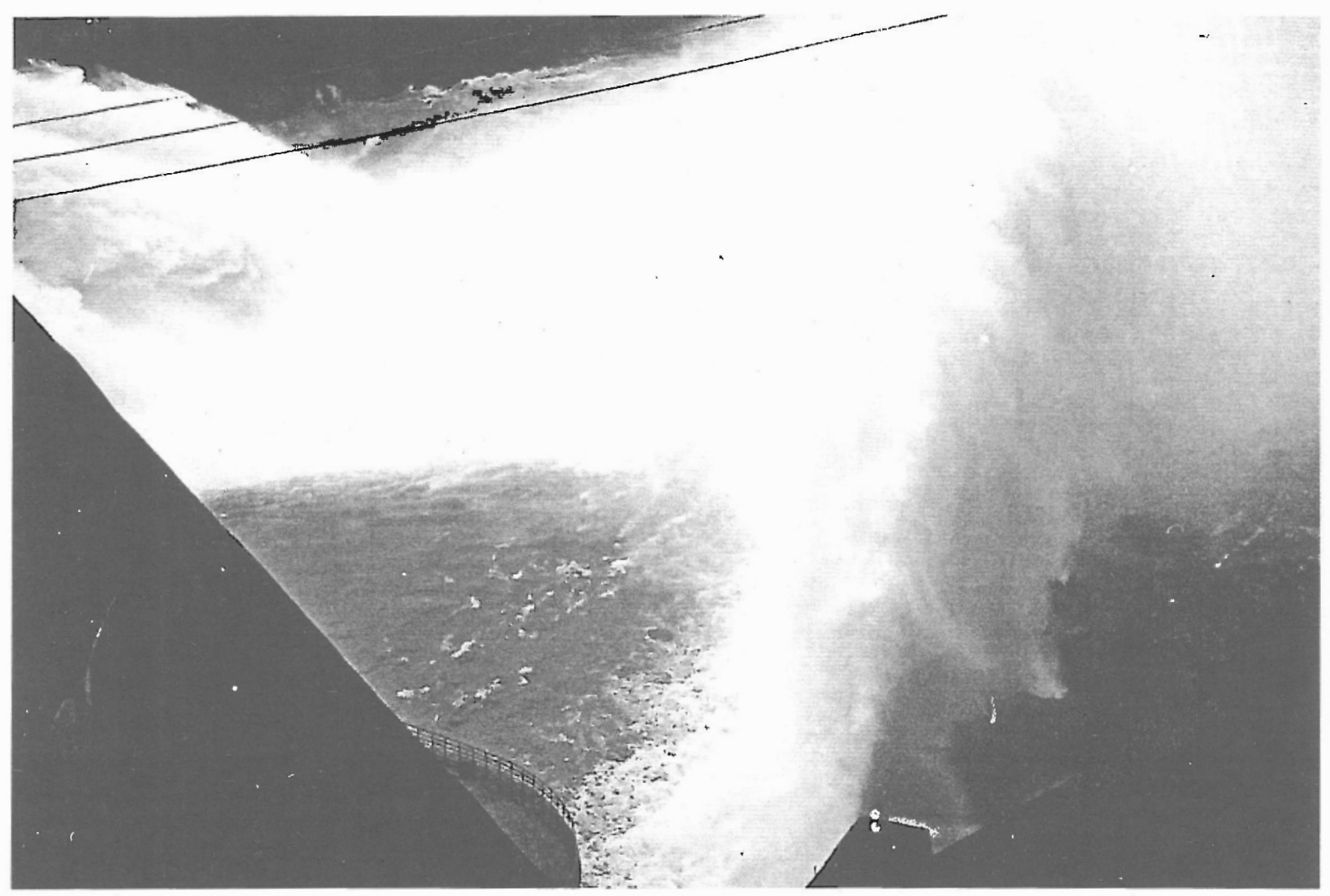

Foto 7 - Pormenor da intensa descarga (1100 $\left.\mathrm{m}^{3} / \mathrm{s}\right)$ pela barragem da Aguieira (foto de M. Morais, na tarde de 27/01/2001).

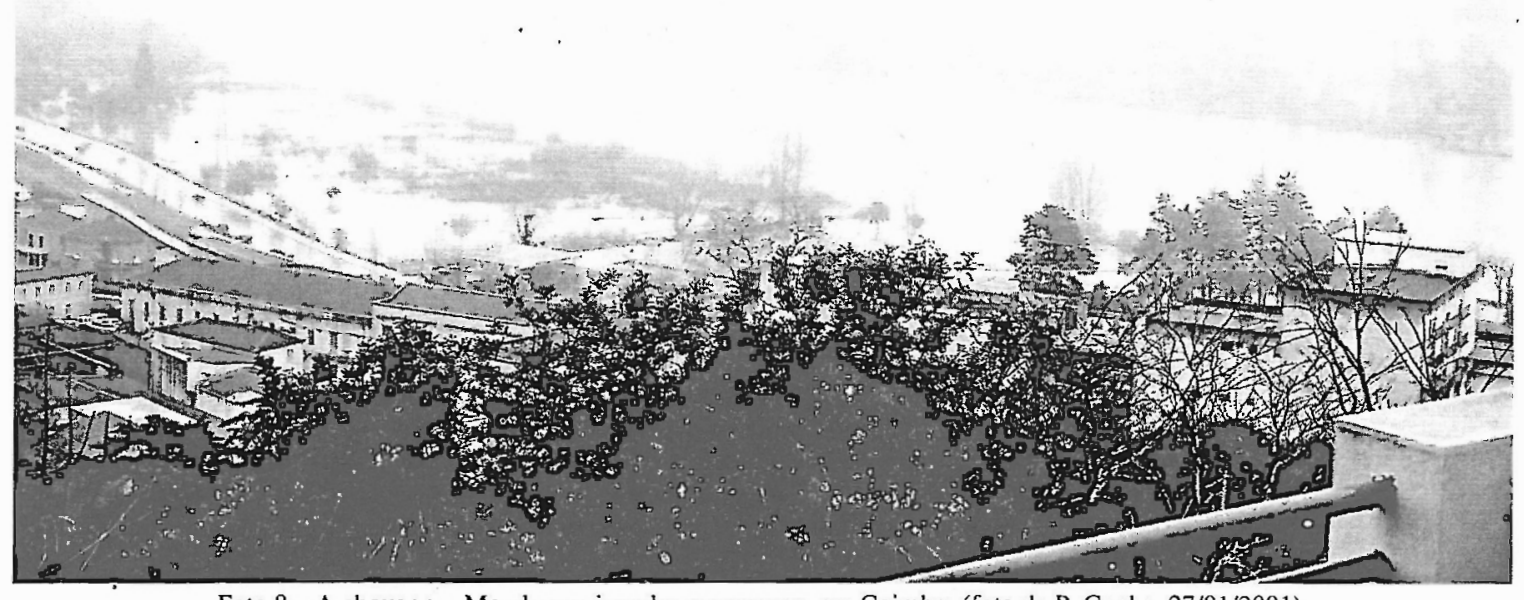

Foto 8 - A chover e o Mondego a inundar as margens, em Coimbra (foto de P. Cunha, 27/01/2001). 


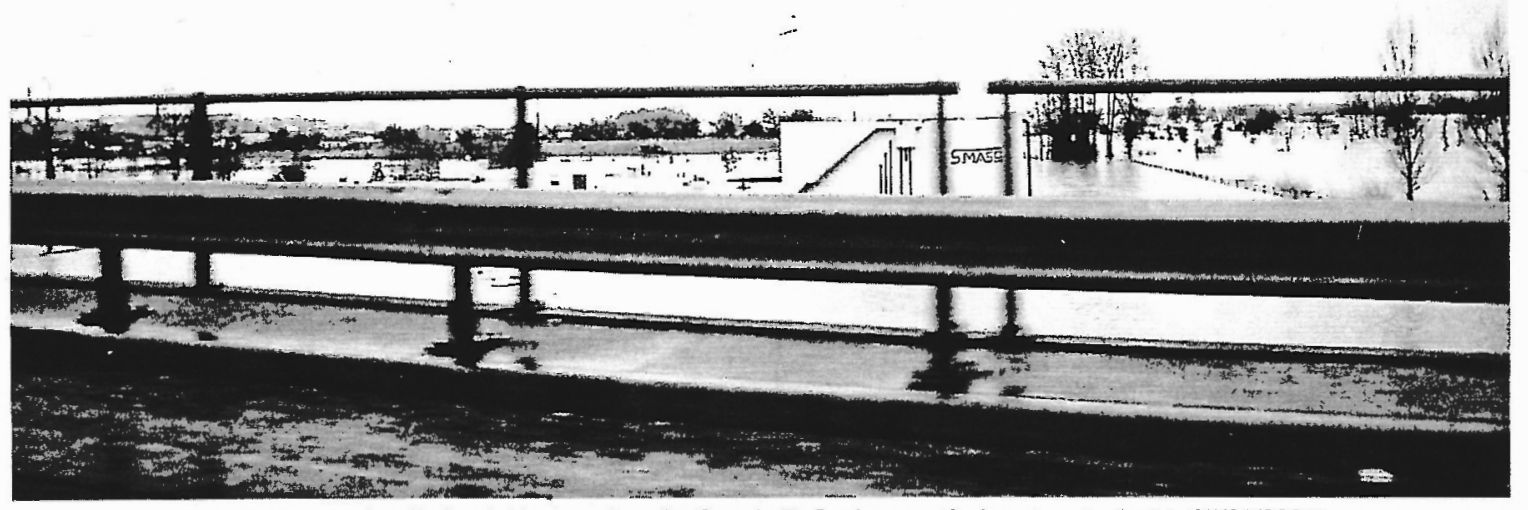

Foto 9 - ETAR de Ribeira de Frades, alagada (foto de P. Cunha a partir da auto-estrada A1, 27/01/2001).

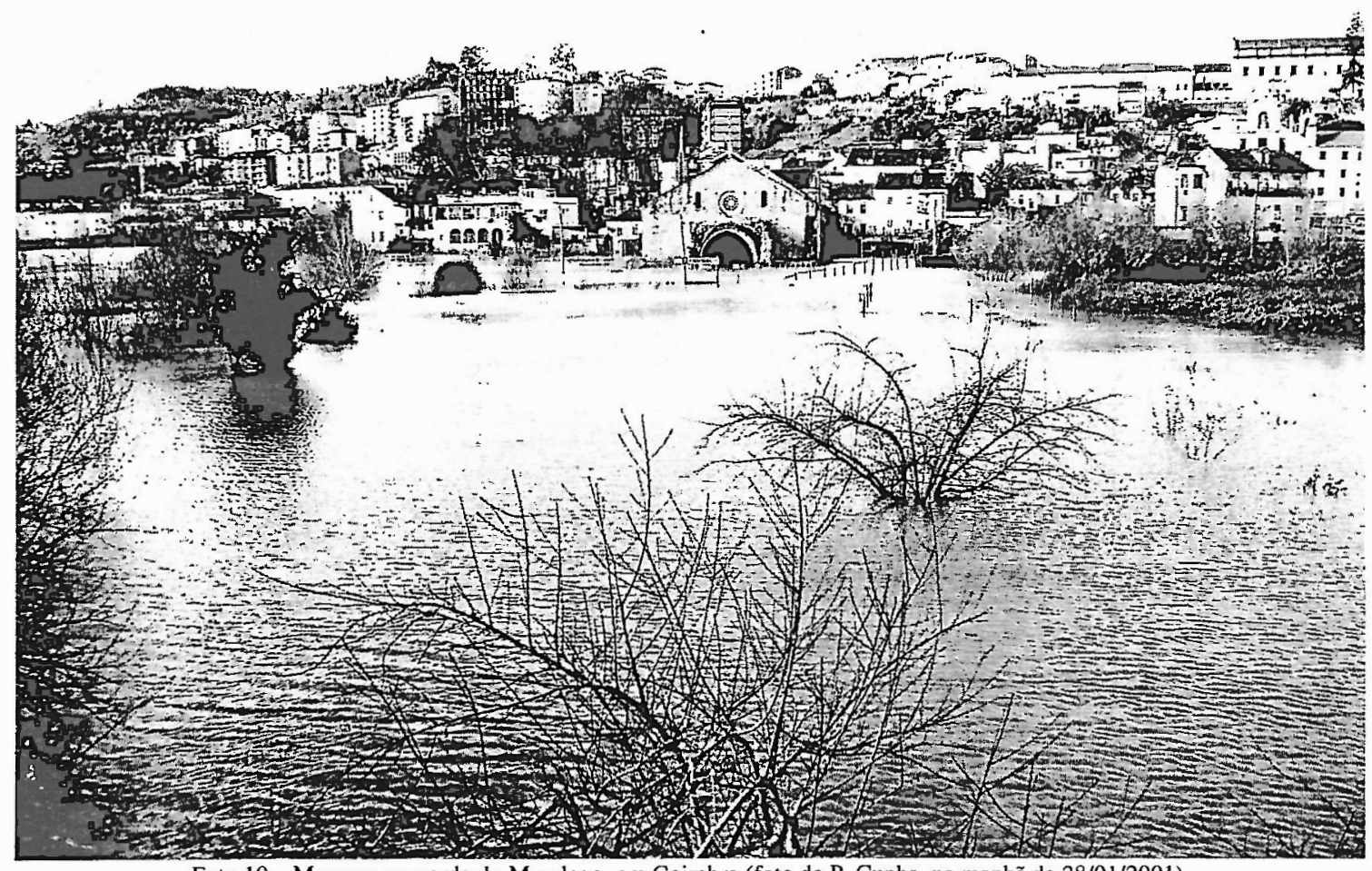

Foto 10 - Margem esquerda do Mondego, em Coimbra (foto de P. Cunha, na manhã de 28/01/2001). 


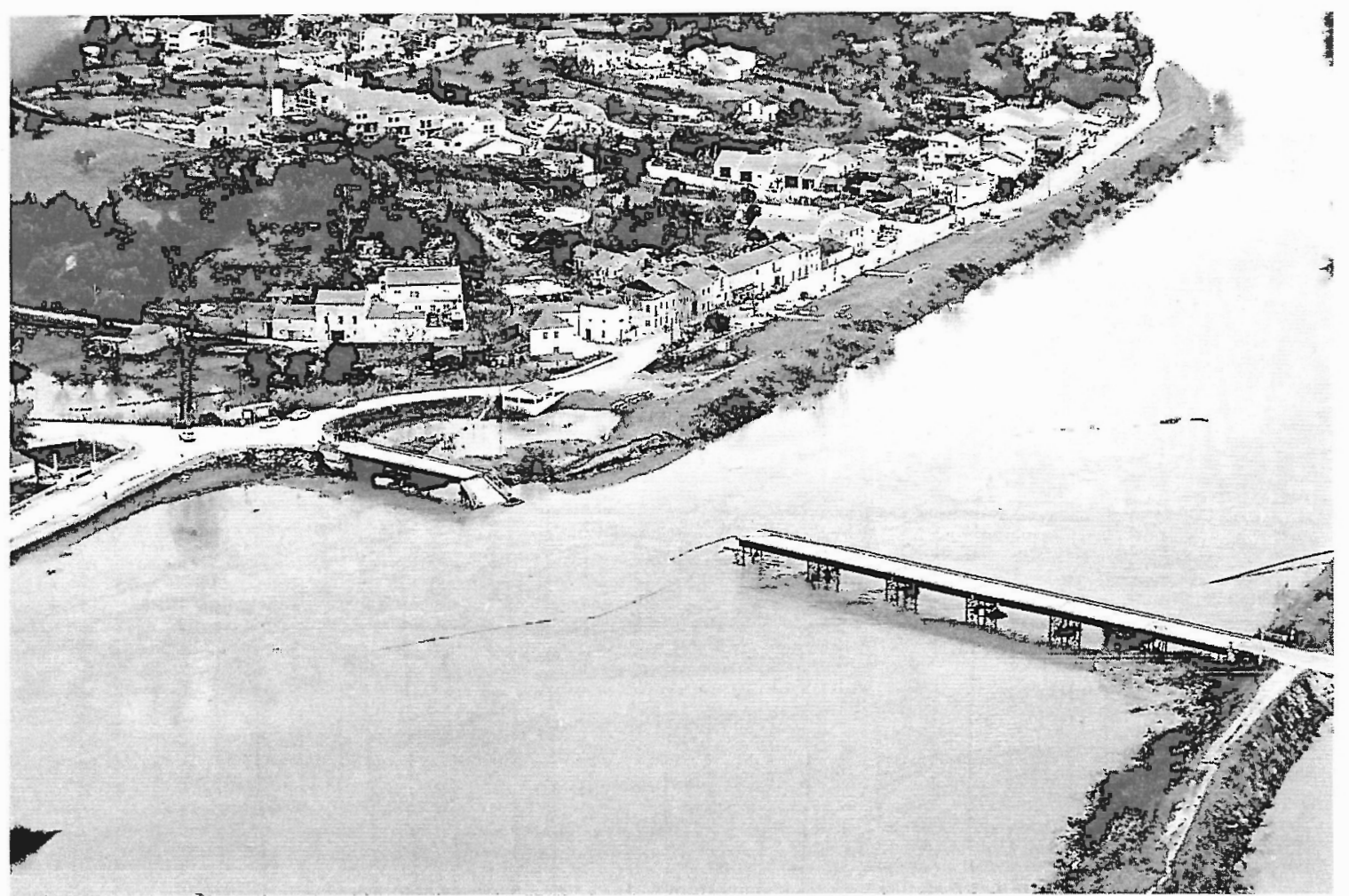

Foto 11 - Vista aérea oblíqua do Leito Periférico Esquerdo, junto a Casal Novo do Rio, observando-se o colapso da ponte das Lavandeiras e a ruptura no dique direito a inundar para Montemor-o-Velho (foto de A. Carriço, pelas 13h de 30/01/2001).

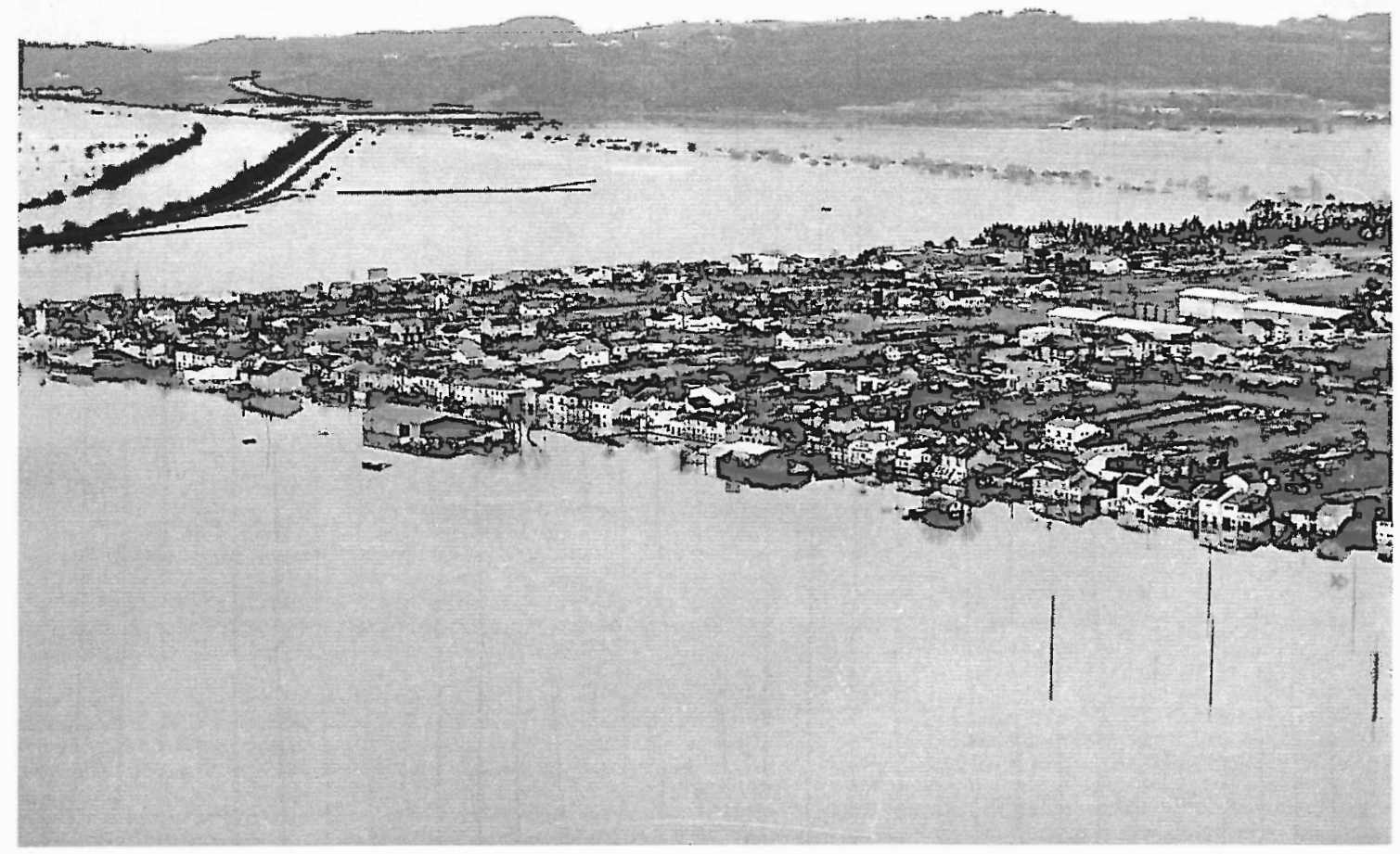

Foto 12 - Vista aérea oblíqua (foto de A. Carriço, 30/01/2001), mostrando em primeiro plano a povoação de Ereira já convertida em ilha; ao fundo, constata-se o completo alagamento da planície aluvial. 


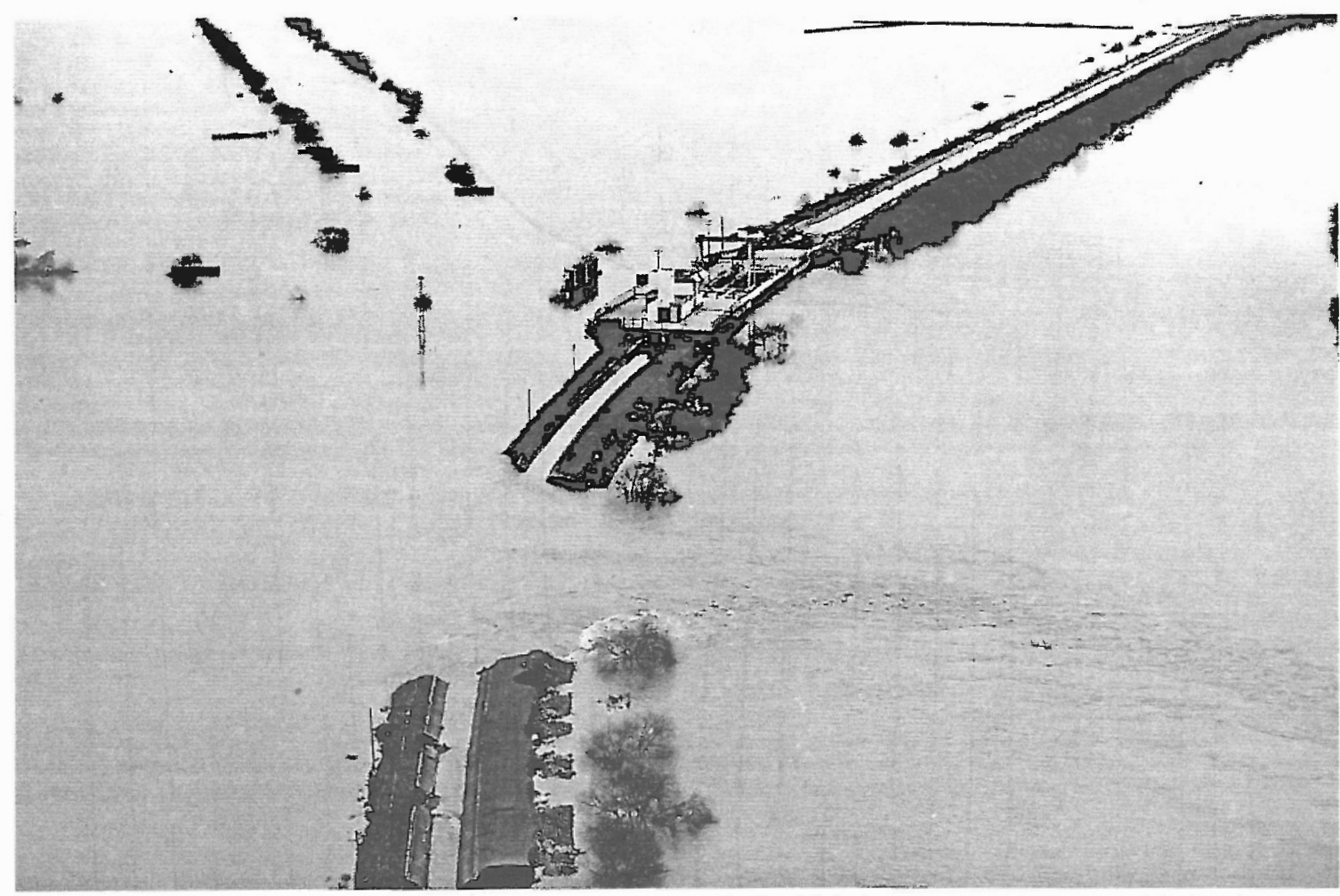

Foto 13 - A água da margem esquerda a romper o dique direito do Canal Principal, junto da Estação Elevatória de Foja, ingressando no Mondego (foto de A. Carriço, 30/01/2001).

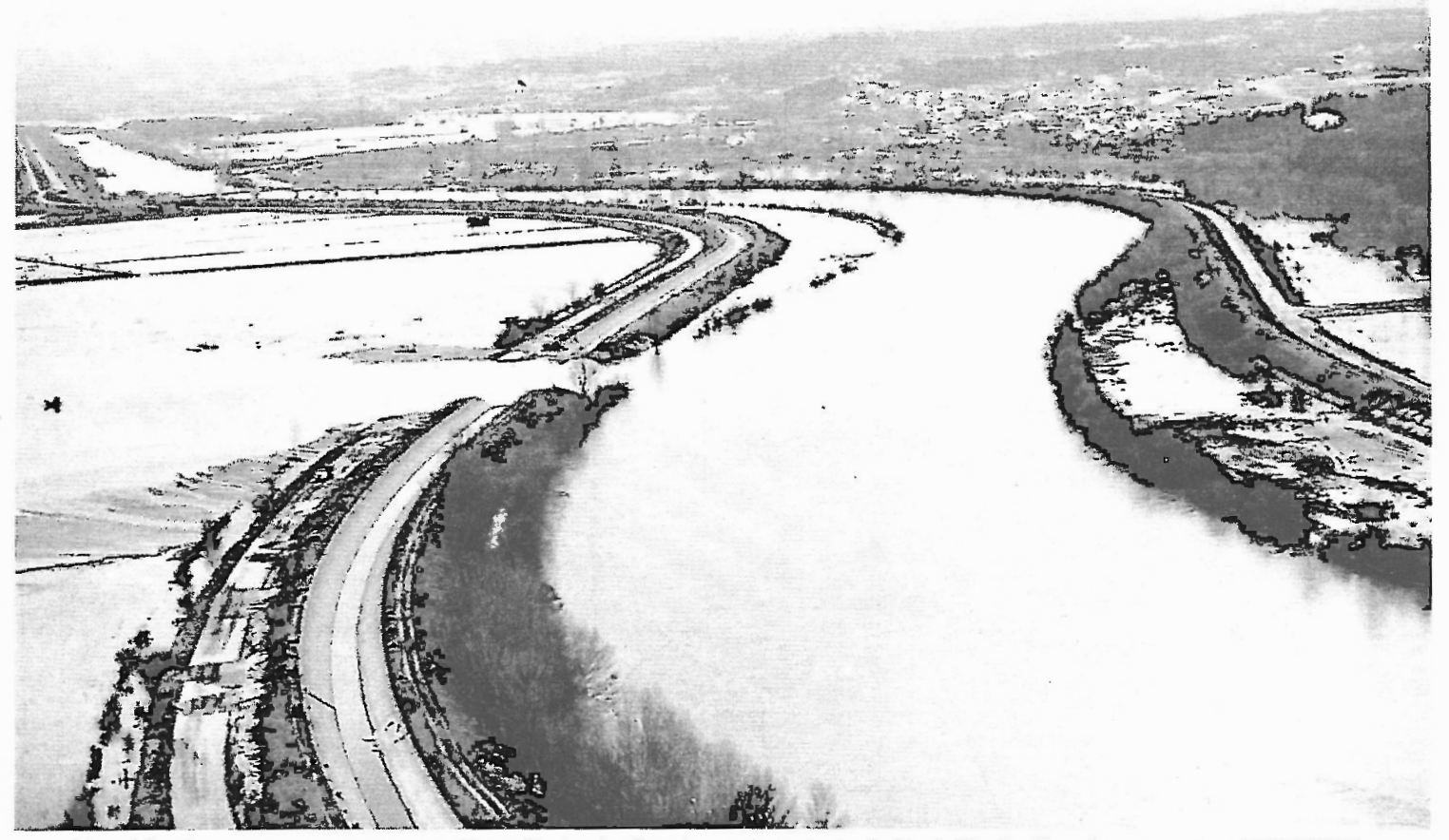

Foto 14 - Panorâmica da ruptura no dique direito do Canal Principal, junto de Santo Varão (foto de A. Carriço, 30/01/2001), permitindo observar o contorno do derrame de areia. 
territorium 9.2002

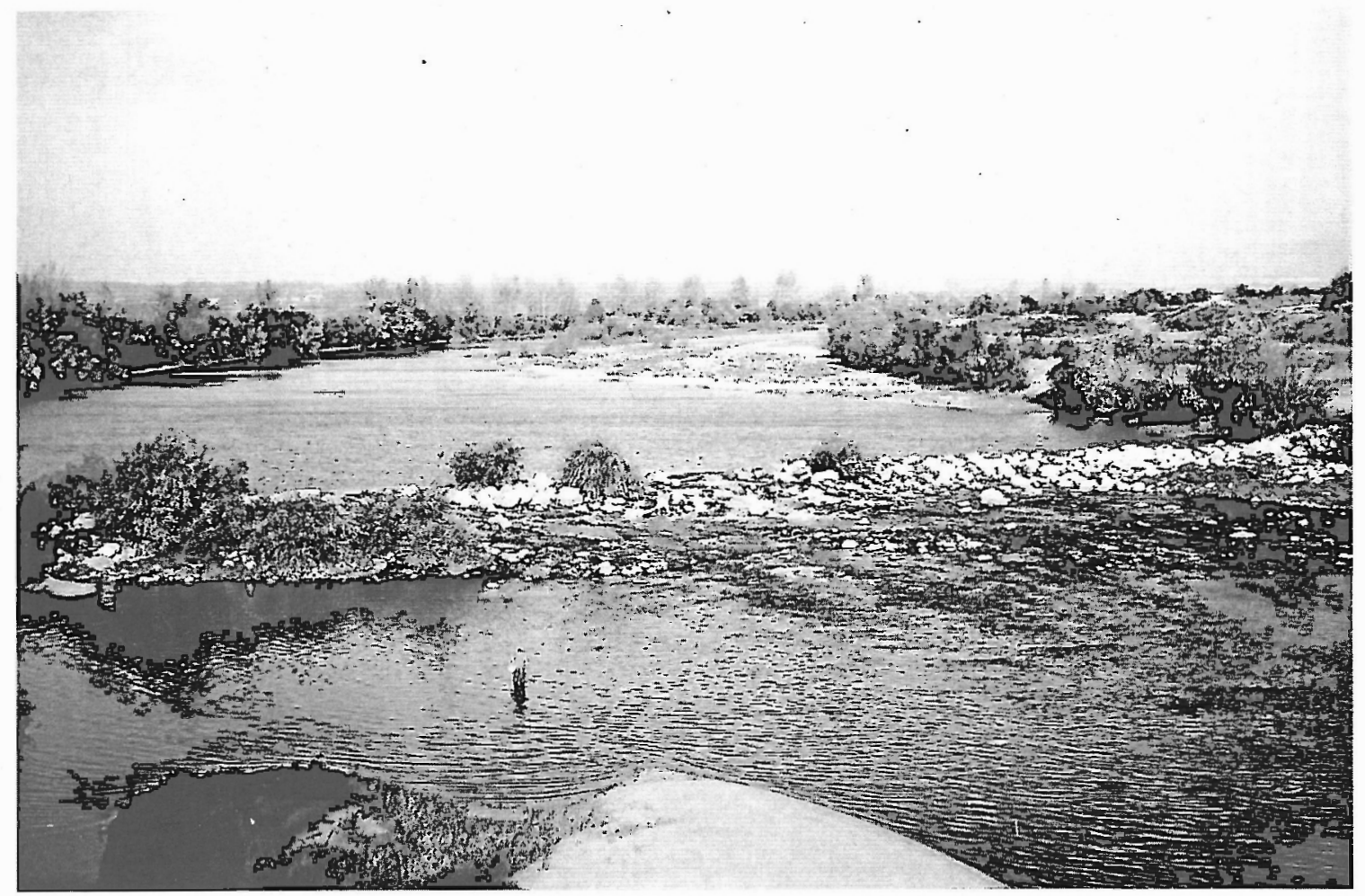

Foto 15 - Açude de Formoselha, no Canal Principal do Mondego (foto de P. Cunha, 8/11/2001).

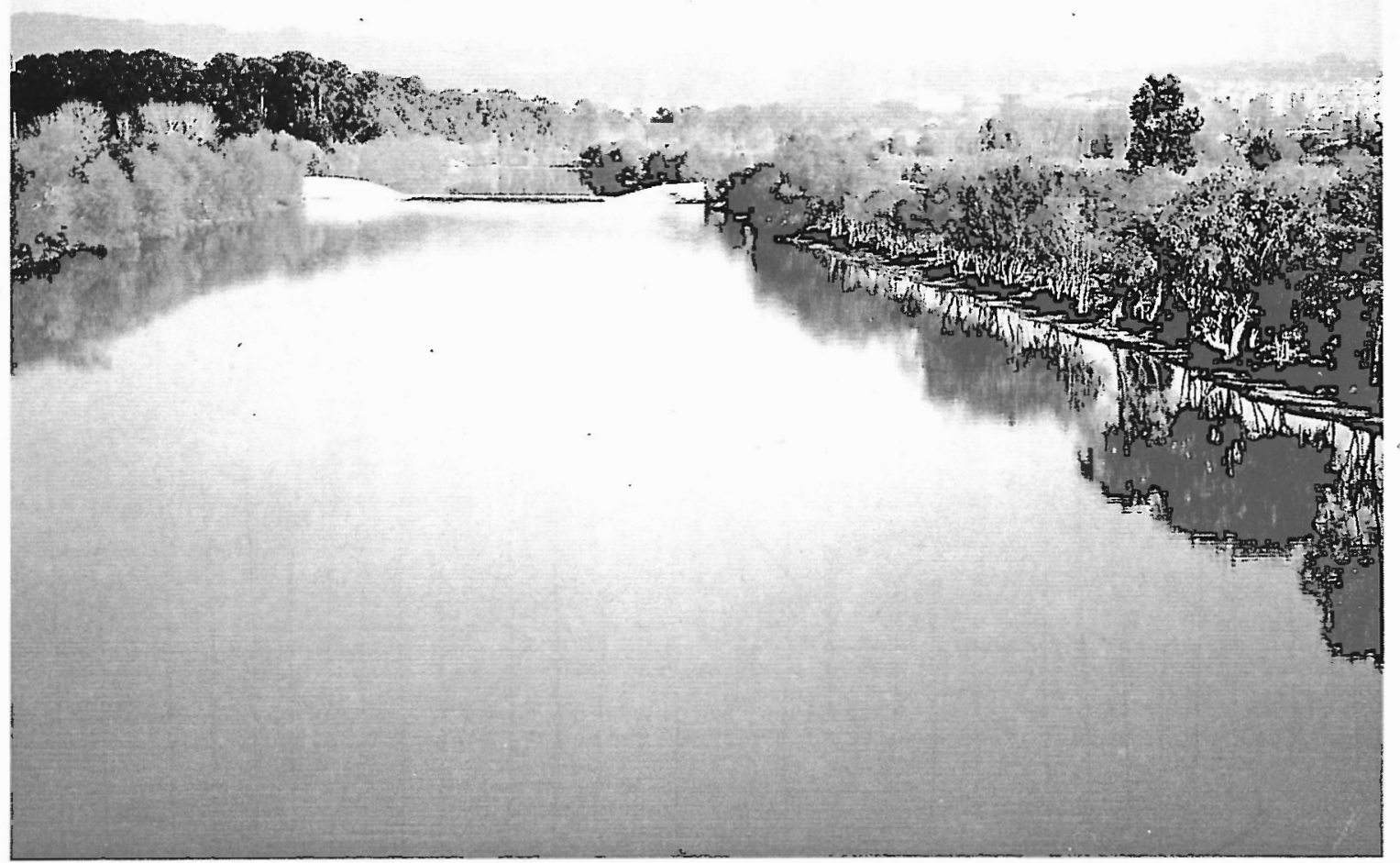

Foto 16 - Vista para montante segundo o Canal Principal do Mondego, observando-se uma secção com esporões laterais e, mais ao fundo, ainda outra (foto de P. Cunha, 8/11/2001). 


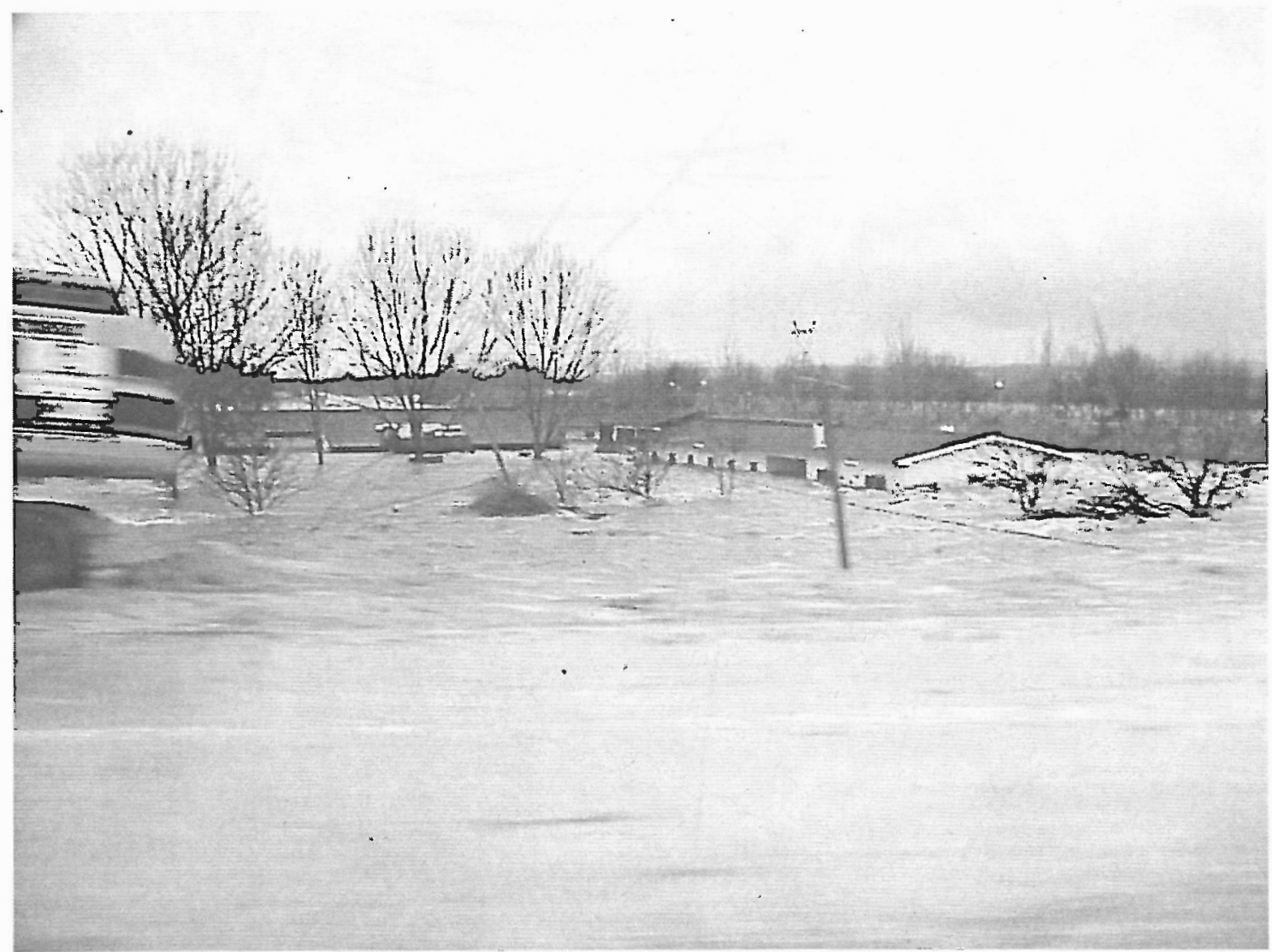

Foto 17 - Ruptura no dique esquerdo do Canal Principal (ao fundo, à direita, na foto), junto aos edifícios de uma quinta agrícola em Ribeira de Frades, a introduzir uma torrente de água. Em primeiro plano, na faixa da auto-estrada Al está uma grua a descarregar pedras para proteger o talude da $\mathrm{A} 1$ (foto de $\mathrm{P}$. Cunha, $27 / 01 / 2001$, pelas $16 \mathrm{~h} 30 \mathrm{~m}$ ). 
